
R. E. Hecky, J. H. Janse, A. Janssen, L. Kaufman, M. A. Kishe-Machumu, J. Kolding, W. Ligtvoet, D. Mbabazi, M. Medard, O. C. Mkumbo, E. Mlaponi, A. T. Munyaho, L. A. J. Nagelkerke, R. Ogutu-Ohwayo, W. O. Ojwang, H. K. Peter, D. Schindler, O. Seehausen, D. Sharpe, G. M. Silsbe, L. Sitoki, R. Tumwebaze, D. Tweddle, K. E. Van de Wolfshaar, H. Van Dijk, E. Van Donk, J. C. Van Rijssel, P. A. M. Van Zwieten, J. H. Wanink, F. Witte, and W. M. Mooij. 2014. Coupled human and natural system dynamics as key to the sustainability of Lake Victoria's ecosystem services. Ecology and Society 19(4): 31. http://dx.doi.org/10.5751/ ES-06965-190431

Research

\title{
Coupled human and natural system dynamics as key to the sustainability of Lake Victoria's ecosystem services
}

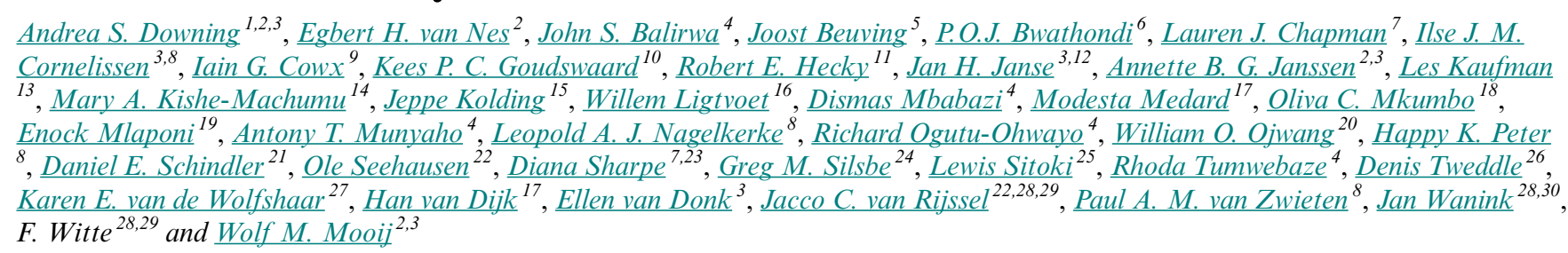

ABSTRACT. East Africa's Lake Victoria provides resources and services to millions of people on the lake's shores and abroad. In particular, the lake's fisheries are an important source of protein, employment, and international economic connections for the whole region. Nonetheless, stock dynamics are poorly understood and currently unpredictable. Furthermore, fishery dynamics are intricately connected to other supporting services of the lake as well as to lakeshore societies and economies. Much research has been carried out piecemeal on different aspects of Lake Victoria's system; e.g., societies, biodiversity, fisheries, and eutrophication. However, to disentangle drivers and dynamics of change in this complex system, we need to put these pieces together and analyze the system as a whole. We did so by first building a qualitative model of the lake's social-ecological system. We then investigated the model system through a qualitative loop analysis, and finally examined effects of changes on the system state and structure. The model and its contextual analysis allowed us to investigate system-wide chain reactions resulting from disturbances. Importantly, we built a tool that can be used to analyze the cascading effects of management options and establish the requirements for their success. We found that high connectedness of the system at the exploitation level, through fisheries having multiple target stocks, can increase the stocks' vulnerability to exploitation but reduce society's vulnerability to variability in individual stocks. We describe how there are multiple pathways to any change in the system, which makes it difficult to identify the root cause of changes but also broadens the management toolkit. Also, we illustrate how nutrient enrichment is not a self-regulating process, and that explicit management is necessary to halt or reverse eutrophication. This model is simple and usable to assess system-wide effects of management policies, and can serve as a paving stone for future quantitative analyses of system dynamics at local scales.

Key Words: eutrophication; feedbacks; fisheries; Lake Victoria; model; multidisciplinary, social-ecological system; sustainability

\section{INTRODUCTION}

Nile perch (Lates niloticus) was introduced to Lake Victoria in the 1950s and suddenly became dominant in the system in the 1980s (Goudswaard et al. 2008). Prior to this dramatic event, the ecosystem of Lake Victoria harbored a large diversity of haplochromine cichlids and a few native tilapia species destined for local and regional markets (Pringle 2005a). The Nile perch boom co-occurred with other major transformations to Lake Victoria's ecosystem, including a collapse of the native diversity of haplochromines and the eutrophication of the lake's waters (Witte et al. 2007a, Hecky et al. 2010).

Despite the dramatic diversity loss and catastrophic ecosystem changes that surrounded the Nile perch invasion, management currently aims to maintain the system in its Nile perch-dominated state, not to recover the former Nile perch-free, diverse ecosystem - should that even be possible. Indeed, Nile perch has become the product of an international export industry worth approximately US\$250 million yearly (Pringle 2005a, Kayanda et

${ }^{1}$ Stockholm Resilience Centre, Stockholm University, Sweden, ${ }^{2}$ Aquatic Ecology and Water Quality Management group, Wageningen University, Netherlands, ${ }^{3}$ Netherlands Institute of Ecology (NIOO-KNAW), Wageningen, Netherlands, ${ }^{4}$ National Fisheries Resources Research Institute (NaFIRRI), Jinja, Uganda, ${ }^{5}$ Department of Cultural Anthropology and Development Studies, Faculty of Social Sciences, Radboud University, Nijmegen, Netherlands, ${ }^{6}$ University of Dar es Salaam, College of Natural and Applied Sciences, Department of Aquatic Sciences and Fisheries, Dar es Salaam, Tanzania, ${ }^{7}$ Department of Biology, McGill University, Montreal, Canada, ${ }^{8}$ Aquaculture \& Fisheries Group, Wageningen University, Netherlands, ${ }^{9}$ Hull International Fisheries Institute, University of Hull, United Kingdom, ${ }^{10}$ Institute for Marine Resource and Ecosystem Studies (IMARES), Wageningen University, Yerseke, Netherlands, ${ }^{11}$ Biology Department and Large Lakes Observatory, University of Minnesota-Duluth, USA, ${ }^{12}$ Netherlands Environmental Assessment Agency (PBL), Bilthoven, Netherlands, ${ }^{13}$ Boston University Marine Program, Biology Department, Boston University, USA, ${ }^{14}$ Tanzania Fisheries Research Institute (TAFIRI), Dar es Salaam, Tanzania, ${ }^{15}$ Department of Biology, University of Bergen, Norway, ${ }^{16}$ Netherlands Environmental Assessment Agency (PBL), The Hague, Netherlands, ${ }^{17}$ Department of Sociology of Development and Change. Social Science Group, Wageningen University, Netherlands, ${ }^{18}$ Lake Victoria Fisheries Organisation, Jinja, Uganda, ${ }^{19}$ Tanzania Fisheries Research Institute (TAFIRI), Mwanza, Tanzania, ${ }^{20}$ Kenya Marine and Fisheries Research Institute (KMFRI), Kisumu, Kenya, ${ }^{21}$ Aquatic \& Fishery Sciences/Department of Biology, University of Washington, USA, ${ }^{22}$ Eawag, Kastanienbaum, Switzerland, ${ }^{23}$ Smithsonian Tropical Research Institute, Panama City, Panama, ${ }^{24}$ Royal Netherlands Institute for Sea Research, Yerseke, Netherlands, ${ }^{25}$ The Technical University of Kenya, Nairobi, Kenya, ${ }^{26}$ South African Institute for Aquatic Biodiversity, Grahamstown, South Africa, ${ }^{27}$ Institute for Marine Resource and Ecosystem Studies (IMARES), Wageningen University, Ijmuiden, Netherlands, ${ }^{28}$ Institute of Biology, University of Leiden, Netherlands, ${ }^{29}$ Naturalis Biodiversity Center, Leiden, Netherlands, ${ }^{30}$ Koeman en Bijkerk bv, Ecological Research and Consultancy, Haren, Netherlands 
al. 2009). Many people migrated to the lake's shores to benefit from the fisheries, a migration that has led to important transformations to the lake's societies. Currently, an estimated 30 million people live in the lake's basin and are shaping and being shaped by its ecology and economy (Awange and Ong'ang'a 2006).

Management measures on Lake Victoria have focused on fisheries and aim to manage a certain quality of catch (size structure of Nile perch) rather than total fishing effort or stock biomass (van der Knaap et al. 2002). Some of these methods are applied on the lake itself; e.g., banning beach seines and increasing the minimum mesh size of gillnets, or introducing fish slot sizes. In the case of Nile perch, measures exist at the processing output level, where there is a minimum length of fish that the factories are allowed to process. Approaches to managing the fisheries assume that the fisher communities, as well as fish stocks, are homogeneous (Muhoozi 2002). Management measures are difficult to implement and monitor given that Lake Victoria is the world's second largest freshwater lake by area $\left(68,800 \mathrm{~km}^{2}\right)$, has a highly convoluted shoreline that is shared by three countries (Tanzania, Uganda, and Kenya), and the fisheries are open access. Also, the effectiveness of regulations is limited, in part because policies can be immediately detrimental to the filleting factories that process the fish for export markets (Johnson 2010). Resources available to implement or enforce policies are scarce, and enforcement can be subject to corruption.

Added to difficulties in choosing and implementing effective management measures, stakeholders and scientists disagree about the current state of the Nile perch fisheries and what the dominant threats to these fisheries are (Witte et al. 2007a). Indeed, owners of filleting factories complain that they are operating their factories at decreasing capacity, overlooking the fact that many of the factories were built at structural overcapacity (Abila and Jansen 1997, Johnson 2010). Some scientists read overfishing in the fishery survey data (Mkumbo et al. 2007, Mkumbo and Mlaponi 2007, Kayanda et al. 2009), while others see a total stock that fluctuates around a stable average despite increased fishing effort. The stable stock under increased pressure rests on the logic that increased productivity results from eutrophication (Kolding et al. 2008).

The cumulative pressures influencing Lake Victoria are multiple, intricately interconnected, and threatening to all its fisheries as well as to the lake's ability to carry out supporting services. Indeed, the whole ecosystem is influenced by climate change (Hecky et al. 2010, Cózar et al. 2012) and has been degraded through eutrophication (Dobiesz et al. 2010), which impoverishes the system by driving an irreversible decline in biodiversity (Seehausen et al. 1997a). Beyond a certain threshold, eutrophication threatens to cause a more general collapse of stocks, not only of Nile perch (Kolding et al. 2008). Additionally, Nile perch is not the only exploited fish. For example, the native pelagic cyprinid Rastrineobola argentea (known as dagaa in Tanzania, omena in Kenya, and mukene in Uganda; herein referred to as dagaa) has become an increasingly important product for local societies (Wanink 1999). Furthermore, since the explosion of Nile perch numbers in the lake, social and economic drivers of fishing effort have changed. Risks and opportunities that face fisher communities have evolved with increasing human population sizes and market value (Beuving 2013). Nile perch is destined predominantly to European markets that impose strict hygiene standards and influence fish prices. Market demand and processing costs influence factory owners, fish buyers, and trade middlemen, who in turn affect the organization of fishing and fisher communities and thus shape stock exploitation (Abila and Jansen 1997, Ponte 2007, van der Knaap and Ligtvoet 2010).

Two lake-wide organizations - the Lake Victoria Fisheries Organisation (LVFO) and the Lake Victoria Basin Commission (LVBC) - have played the most important roles in coordinating research on the lake's resources. While originally conceived as an instrument for holistic, ecosystem-based management, the LVFO has a much stronger fisheries perspective. The LVBC has the potential to address water quality and nonfisheries management issues through its Lake Victoria Environment Management Project Plan II (LVEMPII). So far, coordination of field efforts and data sharing between the two organizations are poor. Fishery science, and to some extent limnology, have undergone a measure of regional integration under LVEMP activities, but on the whole, an ecosystem's view is still distinctly lacking. Dissemination of results has also been limited at times, with LVFO investing greater effort in communications than the LVBC.

In sum, changes in Lake Victoria are a complex product of social, economic, and ecological processes. To comprehend the dynamics of this complex system, to visualize the scenarios likely to result from alternative management measures, and to manage human activities that influence the lake in an intelligent and farsighted manner, the lake and lake basin ecosystem must be understood in their entirety. Many analyses of their parts - for example, water quality, diversity, or fisheries - have been conducted in isolation. Our aim is to connect the dots and study the interactions among the parts of Lake Victoria's system.

An important barrier to assembling the pieces of Lake Victoria lies in quantifying the ecosystem's components in a spatiotemporally representative way. As a first step in this direction, we employed a form of qualitative modeling called loop analysis (Levins 1974). We first built a feedback diagram of Lake Victoria's social-ecological system based on the components and interactions that compose it, matching the model to Lake Victoria's past trends and changes, and investigated the effects of quantitative and structural modifications to the system on its behavior.

\section{SOCIAL-ECOLOGICAL SYSTEM REPRESENTATION}

\section{Qualitative models}

We first created a feedback diagram containing three different types of objects: (1) the key elements of the system, (2) connections between interacting key elements, and (3) the sign of these interactions near equilibrium. If an increase in the value (biomass, concentration, or economic value) of an element causes an increase in a connected element, the sign is positive (+). If, on the other hand, an increase in one causes a decrease in the other, the sign is negative (-). We then carried out the loop analysis, where we identified the feedback loops in the system; i.e., the pathway of interactions that go from any element and back to it, through other elements in the defined system. We also identified whether these feedbacks are overall positive or negative by multiplying the 
signs of the interactions along each pathway. A positive feedback loop reflects a "reinforcing" process, where an increase in one element causes it to increase further: positive feedback loops are therefore destabilizing. A negative feedback loop, on the other hand, is self-regulating: an increase in an element's value leads it to limit itself; a negative feedback loop is stabilizing. We obtained several outputs from this qualitative analysis: (a) a description of the system as a whole, (b) all the direct and indirect pathways connecting different parts of the system, (c) the effect-positive or negative - of the change in one element on its different connections; i.e., chain reactions across the system, (d) the multiple positive and negative controllers of each element, (e) stabilizing and destabilizing feedbacks, and (f) a view of key elements that can alter the sign of a feedback; i.e., those for which connection signs can be changed; e.g., policies.

Determining which elements of a system are key is a subjective process. To reduce bias caused by the oriented knowledge of any single Lake Victoria scientist, scientists in the fields of aquatic ecology, fisheries sciences, and social sciences, as well as stakeholders, all with expertise in Lake Victoria's system, were brought together in a workshop in Dar es Salaam in May 2012. To make the process more manageable, we first built two separate diagrams: one for the ecological subsystem and one for the social subsystem, including fisheries. We then combined the two diagrams into a linked social-ecological system representation. Four groups of scientists and stakeholders with mixed expertise discussed and built the two subdiagrams. These groups thus determined the elements and the interactions to enter the model based on their understanding of underlying processes (e.g., eutrophication) and knowledge of the system (e.g., the types of fishes landed with different nets), and discussed them until the final diagrams satisfactorily represented the perspectives of the different topics (social sciences, water quality, and fisheries). The discussions continued online after the workshop and then included even more participants, who have in turn become the authors of this paper. In this way, the biases that remain are inherent to research conducted on Lake Victoria thus far. This is the first time such diverse perspectives on Lake Victoria's system have been assembled on an equal footing. Our representation of the system as we know it can further point out where ignorance remains.

To make the diagrams tractable, we excluded all self-effects and assumed density dependence to be negative, reflecting a stable system. Also, where interactions are known to be nonlinear, such as the effect of eutrophication on productivity, we cut the process down into its parts: the positive effect of eutrophication on growth, and the positive effect of eutrophication on anoxia and shading, which in turn is negative for growth. We emphasize that the model is not quantitative, and we do not include the weight of each interaction. In this way, our model can represent both locations or time periods where growth processes prevail over negative effects of deoxygenation, and vice versa, and thus represent the full system irrespective of its current state. To make our final linked diagram more parsimonious, we eliminated the elements flanked only by unidirectional positive interactions, as they add detail and complexity to the loops but do not alter their signs - and therefore, have no effect on the overall dynamics of the system.

\section{Ecological subsystem}

The nutrients of the system are represented in nitrogen $(\mathrm{N})$ and phosphorus (P) (Fig. 1) that contribute to an increase in phytoplankton biomass, which is in turn consumed by zooplankton and fish (Fig. 1: phytoplankton --> zooplankton and haplochromines). The major source of nutrient input to the lake is through atmospheric deposition, resulting from intensive land use in the basin, through land clearing and burning (Tamatamah et al. 2005, Hecky et al. 2006) (Fig. 1: from the local and regional economy and society-herein abbreviated to Soc\&econ-to N\&P). An increase in nutrients has a nonlinear effect on the system. Indeed, while there is an initial phase of increase in phytoplankton biomass, as nutrient input continues increasing, phytoplankton biomass begins to limit light availability and eventually reaches an upper limit depending on light extinction and mixing depth (Silsbe et al. 2006). We try to account for this strong nonlinearity by adding phytoplankton's self-shading property and contribution to detritus (Fig. 1: phytoplankton --> shading and detritus). Detritus also increases shading and oxygen consumption, and exists as a trophic pathway for the shrimp Caridina nilotica (Fig. 1: detritus --> shading, anoxia, and C. nilotica).

Fig. 1. Ecological interactions. Green arrows represent growth processes (also identified by + sign); blue arrows represent mortality processes (associated with - signs); thick dotted lines and arrows represent complex systems/interactions not further developed. E refers to environmental variables, $F$ to fish variables, $\mathrm{L}$ to limnological variables, and $\mathrm{S}$ to societal variables. E1 = climate change; F1 = large Nile perch; F1' = small Nile perch; F2 = Rastrineobola argentea $; \mathrm{F} 3=$ haplochromines; $\mathrm{L} 1=$ nitrogen and phosphorus; $\mathrm{L} 2=$ phytoplankton; L3 = zooplankton; L4 = detritus; L5 = Caridina nilotica; L6 = shading; L6' = anoxia; S4 = local and regional economy and society.

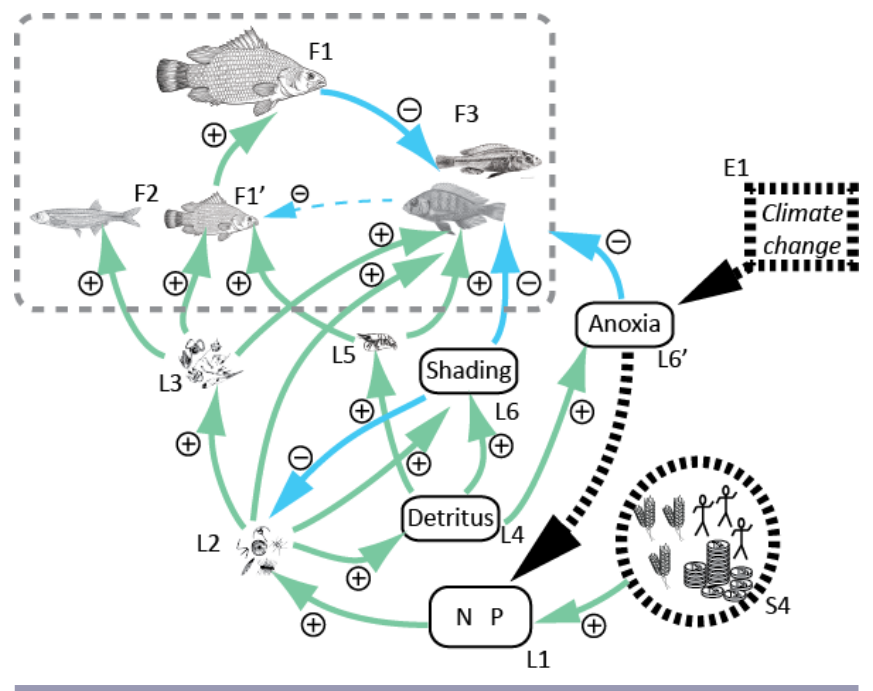

The shrimp C. nilotica is an important detritivore and became an important prey for juvenile Nile perch as well as for the mostly zooplanktivorous haplochromines that remained in the $1990 \mathrm{~s}$ (Downing et al. 2012a) (Fig. 1: C. nilotica --> small Nile perch 
and haplochromines). Recovering haplochromines have mostly reverted to feeding on zooplankton and other small invertebrates but they include shrimp and larger prey in their diets when these are abundant (Kishe-Machumu 2012, van Rijssel and Witte 2013). Light is of primary importance to haplochromines because they rely on color vision for successful breeding and efficient feeding (Seehausen et al. 1997a, Witte et al. 2013) (Fig.1: shading --o haplochromines). Poor light can also alter haplochromine species diversity by promoting hybridization (Seehausen et al. 1997a, Seehausen 2009).

We connected anoxia negatively to all fish since reduced oxygen is ultimately detrimental to them all, though usually through a complex nonlinear process (Fig. 1: anoxia --o all fish). In a first step, an anoxic deep water layer reduces the habitable part of the water column for sensitive species, and increases habitat overlap between species (Vonlanthen et al. 2012). Habitat overlap can result in increased predation rates of Nile perch on haplochromines, as well as hybridization rates between haplochromine species. In a later step, the seasonal upwelling of deep anoxic waters can lead to large fish kills (Ochumba 1990, Gophen et al. 1995). Reduced oxygen concentrations also have a chronic negative effect on species by influencing their metabolic processes and growth rates (Kolding 1993, Rutjes et al. 2007).

Additionally, oxygen plays a complex role in biogeochemical cycles: denitrification-a process that converts nitrate to dinitrogen gas $\left(\mathrm{N}_{2}\right)$ - takes place primarily in anoxic conditions, and these conditions also promote phosphorus release (Fig. 1: anoxia --> N\&P). The effect of oxygen on biogeochemical cycles is temperature sensitive (Veraart et al. 2011), and both weather and temperature conditions influence the duration and extent of water stratification in the lake (Sitoki et al. 2010). These processes are thus likely to be greatly affected by climate change in complex and nonlinear ways (Fig. 1: dashed line from E1 --> anoxia --> N\&P).

Besides the solid arrow indicating Nile perch predation on haplochromines, a dashed arrow was included to indicate the hypothesized negative effect of haplochromines on Nile perch recruitment. It has long been speculated that through either competition or predation, haplochromines have, or had, a negative influence on the growth of small Nile perch, in a process termed depensation (Fig. 1: haplochromines --o small Nile perch) (Walters et al. 1997, Walters and Kitchell 2001, Goudswaard et al. 2008, Downing et al. 2012b). However, a recent study suggests that such an interaction probably did not play a significant role at the scale of the whole lake (Downing et al. 2013a). Depensation should be included only in cases and areas where there is a demonstrated negative influence on the stock-recruitment relationship.

\section{Society and fisheries}

Catches of small Nile perch, dagaa, and haplochromines feed a regional market (in the lakeshore and neighboring countries) (Fig. 2: small Nile perch, dagaa, and haplochromines --> local and regional market; herein abbreviated as LocMar), and catches of large Nile perch go to a European export market (Fig. 2: Nile perch --> international market; herein abbreviated as IntMar). Markets convert catches into investment power, which allows the economy to grow, fuels further investment in alternative sources of income (such as agriculture and farming, or support businesses, including housing, transport, or entertainment), and stimulates human population growth. This growth feeds back into the regional market. The local and regional markets invest in boat or camp owners to ensure their supply of fish. Owners in turn convert their capital into effort, thus further increasing total catch (Fig. 2: IntMar and LocMar --> owners; IntMar and LocMar --> Soc\&econ).

Fig. 2. Socio-economic interactions. Green arrows represent growth processes (also identified by + sign); blue arrows represent mortality processes (associated with - signs); rust arrows represent investment; thick dotted lines and arrows represent complex systems/interactions not further developed. E2 = international economy; E3 = policies; F1 = large Nile perch; F1' = small Nile perch; F2 = Rastrineobola argentea; F3 = haplochromines; F4 $=$ Nile perch fishing effort; F5 $=R$. argentea fishing effort; $\mathrm{S} 1$ = boat and camp owners; $\mathrm{S} 2=$ international market; $\mathrm{S} 3$ = local and regional market; $\mathrm{S} 4=$ local and regional economy; S4' = local society.

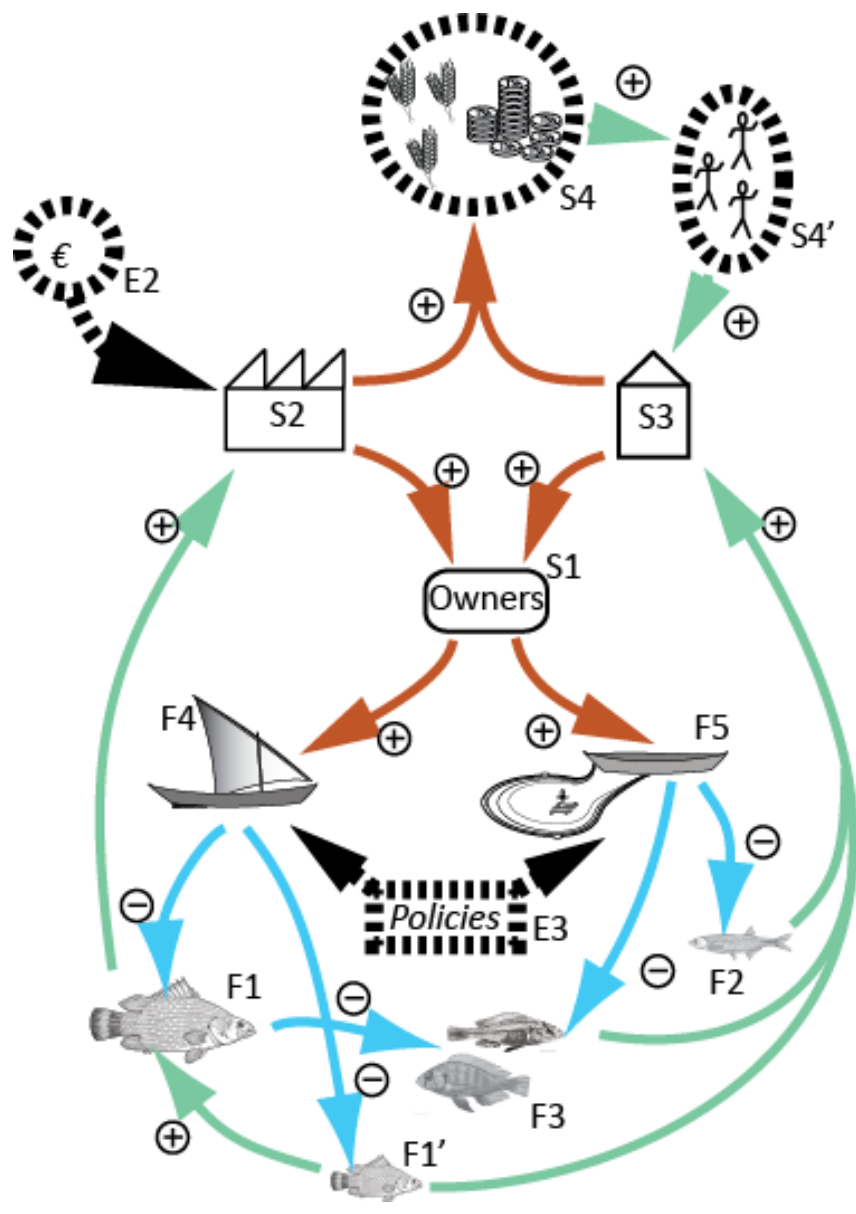

By separating camp and boat owners from the rest of society, we have the means to reflect social, political, and economic disparity. Owners are entrepreneurs, drawing either on their own funds and 
profits or on investments by industries, and they themselves can invest in further effort and gain. Labor, however, is cheap, always abundant enough, and plays a role in every industry: we therefore neglected its impact on owners. Owners can switch between the international Nile perch fishery and regional fisheries or be part of both (Fig. 2: owners --> Nile perch and dagaa fishing effort), depending on the status of the owners and the benefits each fishery yields.

We added two exogenous processes to this diagram that influence the cost-benefits that in turn regulate where owners focus their investments: the international economy and policies (Fig. 2). The international economy, driven by many more products, trends, and fashions than the resources of Lake Victoria, can influence the price Nile perch fetches, as well as quality requirements of the Nile perch destined for export (Kambewa 2007, Ponte 2007, Johnson 2010) (Box 1). This international influence is in large part independent of conditions in the lake but nonetheless defines many of the costs in the Nile perch industry (e.g., installing and maintaining storage and hygiene facilities, or higher investment in societies through eco-labeling requirements) and therefore shapes the catch level necessary to offset costs and reap a benefit (van der Knaap et al. 2002, van der Knaap and Ligtvoet 2010).

Box 1: Influence of the international market

European markets set regulations on the quality of the fish they imported, which created a need for filleting factories to invest in technologies such as freezers and insulated trucks to obtain quality certifications (Johnson 2010) (Fig. 3: international economy(+) --> IntMar --> owners --o Nile perch fishing effort...). European regulations caused import bans several times in the late 1990s because of poor hygiene. During these periods, Nile perch was exported to alternative markets, such as Japan, though at lower prices, and fishing effort was temporarily reduced (Fig. 3: international economy(-) --o IntMar--o Nile perch fishing effort --> Nile perch...) (van der Knaap et al. 2002). Such sanctions or a collapse in the international market can close up the pathways that promote investment in fishing by owners. Such effects could percolate down to show a positive effect on stocks (e.g., Fig. 3: international economy(-) --> IntMar --> owners --> Nile perch fishing effort and dagaa fishing effort --o Nile perch, dagaa, and haplochromines). However, this depends on the importance or adaptability of the local market relative to the international one, as a collapse of the international economy could simply shift dynamics toward the local and regional market, if the local market has a substantial income-source independent of fisheries.

\section{The social-ecological system}

We combined both diagrams and simplified the model to make it manageable. We summarized the positive interactions that dominate the ecological perspective into two main processes: the positive effects of nutrient input that promote growth in fish species (Fig. 3: N\&P --> Nile perch, dagaa, and haplochromines), and the negative effects that come from enrichment but are represented by anoxia and shading (Fig. 3: N\&P --> shading --> Nile perch, dagaa, and haplochromines).
We removed small Nile perch from the fish groups. Instead, Nile perch as a whole contribute to both the regional and international markets (Fig. 3: Nile perch --> IntMar and LocMar). The population size structure of Nile perch has changed since its first introduction, though trends in these changes vary spatially (Kolding et al. 2008) and are likely a response to both the environment - through diet changes - and to size-selective fishing (Downing et al. 2013c).

We merged society and the economy into one since they are connected with positive interactions. Here, they directly contribute to nutrient enrichment (Fig. 3: Soc\&econ --> N\&P).

Fig. 3. Social-ecological system interactions. Green arrows represent growth processes (also identified by + sign); blue arrows represent mortality processes (associated with - signs); rust arrows represent investment; thick dotted lines and arrows represent complex systems/interactions not further developed. $\mathrm{E} 1$ = climate change; $\mathrm{E} 2$ = international economy; $\mathrm{E} 3$ = policies; F1 = Nile perch; F2 = Rastrineobola argentea $; \mathrm{F} 3=$ haplochromines; F4 $=$ Nile perch fishing effort; F5 $=R$. argentea fishing effort; $\mathrm{L} 1=$ nitrogen and phosphorus; L6 = anoxia and shading; $\mathrm{S} 1$ = boat and camp owners; $\mathrm{S} 2=$ international market; $\mathrm{S} 3$ = local and regional market; $\mathrm{S} 4=$ local and regional economy and society.

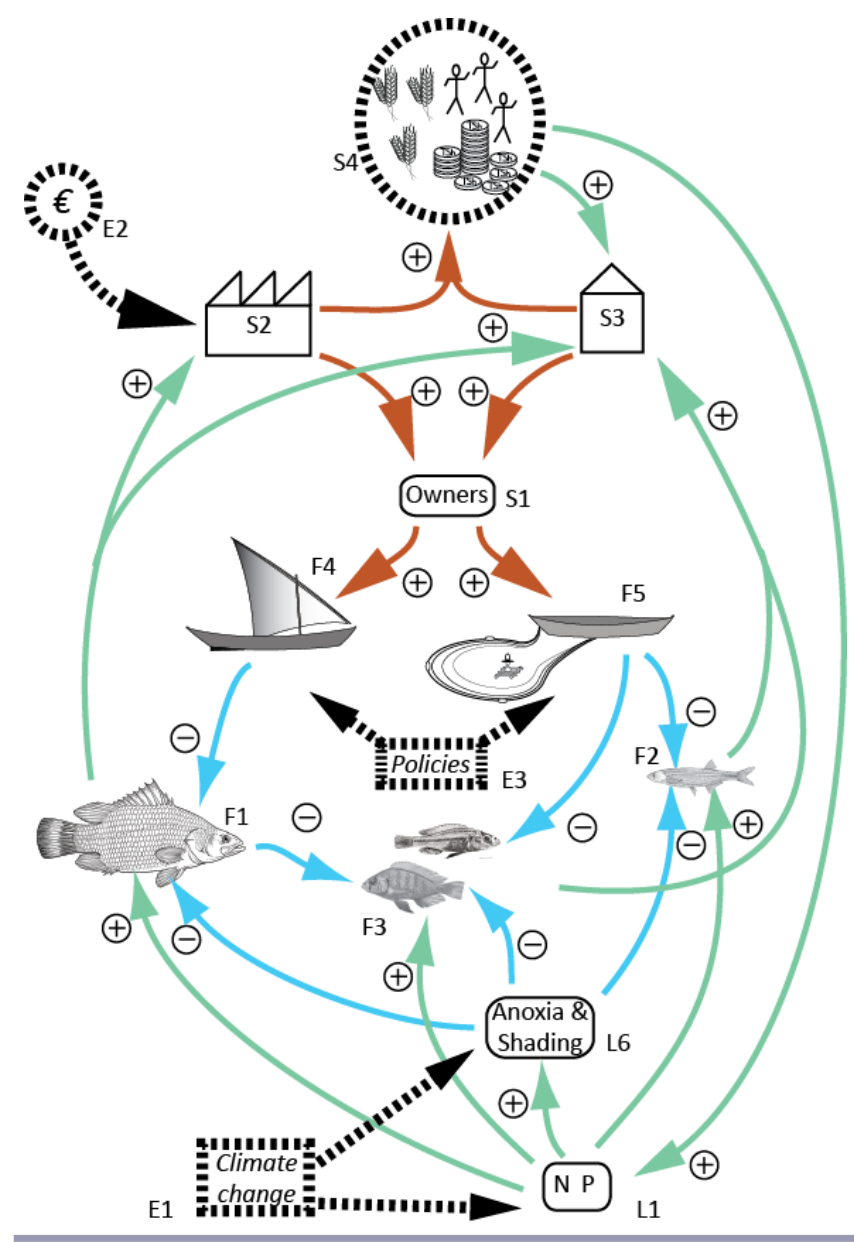




\section{Loop analysis}

Our social-ecological system diagram has 25 loops. We excluded the direct feedback between local market and society from our analysis since it holds no emergent information. Among the remaining 24 loops, we separated nutrient-driven processes, including nine "enrichment" loops (Table 1), in which nutrients lead to stock growth, increased fishing, and economic and population growth, and thus more enrichment, and nine "eutrophication" loops (Table 2), where stronger nutrient input leads to anoxia and shading, influences stock growth as well as economic and population expansion, and thus controls nutrient input. Additionally, we have six "exploitation" loops (Table 3) that describe dynamics from the different stocks through to the markets and back.

Table 1. Enrichment loops and their signs. N;P = nitrogen and phosphorus; $\mathrm{Np}$ = Nile perch; IntMar = international market; Soc\&econ = society and economy; LocMar = local and regional market; Haplo = haplochromines; Dagaa $=$ Rastrineobola argentea $;-->=$ positive interaction; $--\mathrm{o}=$ negative interaction .

\begin{tabular}{lc}
\hline \hline Loop & Sign \\
\hline 1.N;P-->Np-->IntMar-->Soc\&econ-->N;P & + \\
2. N;P-->Np-->LocMar-->Soc\&econ-->N;P & + \\
3. N;P-->Haplo-->LocMar-->Soc\&econ-->N;P & + \\
4. N;P-->Dagaa-->LocMar-->Soc\&econ-->N;P & + \\
5. N;P-->Np--oHaplo-->LocMar-->Soc\&econ-->N;P & - \\
6. N;P-->Np-->IntMar-->owners-->Dagaa effort--oHaplo--> & - \\
LocMar-->Soc\&econ-->N;P & - \\
7. N;P-->Np-->IntMar-->owners-->Dagaa effort--oDagaa--> & - \\
LocMar-->Soc\&econ-->N;P & - \\
8. N;P--->Haplo-->LocMar-->owners-->Np effort--oNp--> & - \\
IntMar-->Soc\&econ-->N;P & \\
9. N;P-->Dagaa-->LocMar-->owners-->Np effort--oNp--> & - \\
IntMar-->Soc\&econ-->N;P &
\end{tabular}

Positive enrichment loops go from nutrients promoting the growth of stocks, through their positive effect on markets, then society, and back to nutrient input (Table 1). Negative eutrophication feedback loops follow the link between nutrients and anoxia and shading. Anoxia and shading are the drivers on stocks whose negative effects cascade to markets and society, and thus lead to reduced nutrient input (Table 2). In the case of negative exploitation loops, they link each stock, through to the market it trades to, back to owners, increased effort, and thus a reduction in stock (Table 3), which is ultimately self-regulating.

Besides these expected loops, we obtained a few inverse loops, where enrichment is self-regulating, while eutrophication and exploitation are self-reinforcing (negative loops in Tables 1 and 3; positive loops in Table 2). These inverted-sign loops describe longer - and presumably weaker through their indirectnesschain reactions stemming from the presence of alternative sources of income for society.

Exploitation loops are mostly self-regulating, implying that as a stock dwindles, its exploitation costs increase and it invites less fishing effort (Table 3: negative loops). However, here we see that exploitation loops can connect two fisheries either directly (Table
3: loops 3 and 5) or indirectly through owners or the local market. These stocks are thus not independent in the eyes of exploitation. For example, pelagic, zooplankton-eating haplochromines can make up a large fraction of the dagaa bycatch. This could compensate for dwindling dagaa stocks since there is no barrier to continuing exploitation in similar ways if, for a time at least, the fish initially targeted is easily replaced (Box 2). In the same way, local and international markets provide outlets for small and large Nile perch, respectively. Therefore, if a size class becomes less available, fishing camp owners would not necessarily see diminishing returns immediately (Table 3: loops 1 and 2). The exact dynamics would of course depend on the price that different fish and fish-size classes fetch, and the fact that these prices are subject to demand-driven fluctuations. In the short term, this might be perceived as evidence of functional complementarity, a benefit of diversity. However, it also signifies a dampening of the self-regulating nature of the negative feedback.

Table 2. Eutrophication loops and their signs. N;P = nitrogen and phosphorus; Anox\&Shade $=$ anoxia and shading; $\mathrm{Np}=$ Nile perch; IntMar = international market; Soc\&econ = society and economy; LocMar = local and regional market; Haplo = haplochromines; Dagaa $=$ Rastrineobola argentea $;-->=$ positive interaction; $--\mathrm{O}=$ negative interaction.

\begin{tabular}{lc}
\hline \hline Loop & Sign \\
\hline 1. N;P-->Anox\&Shade--oNp-->IntMar-->Soc\&econ-->N;P & - \\
2. N;P-->Anox\&Shade--oNp-->LocMar-->Soc\&econ-->N;P & - \\
3. N;P-->Anox\&Shade--oHaplo-->LocMar-->Soc\&econ-->N;P & - \\
4. N;P-->Anox\&Shade--oDagaa-->LocMar-->Soc\&econ-->N;P & - \\
5. N;P-->Anox\&Shade--oNp--oHaplo-->LocMar-->Soc\&econ--> & + \\
N;P & \\
6. N;P-->Anox\&Shade--oNp-->IntMar-->owners-->Dagaa & + \\
effort--oHaplo-->LocMar-->Soc\&econ-->N;P & + \\
7. N;P-->Anox\&Shade--oNp-->IntMar-->owners-->Dagaa & + \\
effort--oDagaa-->LocMar-->Soc\&econ-->N;P & \\
8. N;P-->Anox\&Shade--oHaplo-->LocMar-->owners-->Np & + \\
effort--oNp-->IntMar-->Soc\&econ-->N;P & \\
9. N;P-->Anox\&Shade--oDagaa-->LocMar-->owners-->Np & + \\
effort--oNp-->IntMar-->Soc\&econ-->N;P & + \\
\hline
\end{tabular}

Table 3. Exploitation loops and their signs. $\mathrm{Np}=$ Nile perch; IntMar = international market; Soc\&econ = society and economy; LocMar = local and regional market; Haplo = haplochromines; Dagaa $=$ Rastrineobola argentea $;-->=$ positive interaction; $--\mathrm{o}=$ negative interaction.

\begin{tabular}{lcc}
\hline \hline Loop & Sign \\
\hline 1 Np-->IntMar-->owners-->Np effort--oNp & - \\
2 Np-->LocMar-->owners-->Np effort--oNp & - \\
3 Haplo-->LocMar-->owners-->Dagaa effort--oHaplo & - \\
4 Dagaa-->LocMar-->owners-->Dagaa effort--oDagaa & - \\
5 Np--oHaplo-->LocMar-->owners-->Np effort--oNp & + \\
6 Np-->IntMar-->Soc\&econ-->LocMar-->owners-->Np effort-- & - \\
oNp & \\
\hline
\end{tabular}


Box 2: Connectedness of the fisheries

Haplochromine populations in the offshore and pelagic waters were on a steep decline from the late 1970s and collapsed to low levels in the wake of the Nile perch boom (Witte et al. 1992). Surprisingly, haplochromine biomass started recovering in the early 1990s (Seehausen et al. 1997b) and quickly achieved precollapse pelagic stock biomass (Witte et al. 2007b). Haplochromines now represent up to $80 \%$ of the pelagic fish biomass, and together with dagaa, they constitute more than $50 \%$ of the lake's total fish biomass (Tumwebaze 1997, Wanink 1999, Kayanda et al. 2009). In Tanzania, since their resurgence, haplochromines have shifted from being an important bycatch of the dagaa fishery (sometimes constituting $50-90 \%$ of the catch) (Witte et al. 2000) to becoming a target that is sold to regional markets or is used as bait in the Nile perch fishery (Ngupula and Mlaponi 2010). Indeed, since the mid-1990s, the dagaa fishery has harvested an increasing amount of zooplanktivorous (genus Yssichromis), benthivorous, and detritivorous haplochromines (Haplochromis "paropius-like," also referred to as Haplochromis "broken bar" in Seehausen et al. [1997b]) (van Rijssel, personal observation), indicating that benthic species migrate up at night (Kishe-Machumu 2012), and that the dagaa nets - extending 10 $m$ deep - can influence benthic populations. The relative abundance of dagaa and haplochromines in catches is site- and season-specific, suggesting that the dagaa-haplochromine interaction hides multiple underlying drivers. While fishers and markets in Tanzania have adapted and now specifically target haplochromines, in Uganda and Kenya, haplochromines are still only bycatch, though they are sold on local markets. The scale of haplochromine bycatch is clearly indicative that dagaa fishing methods are not selective enough, which is important because haplochromines have slower growth rates than dagaa, are more sensitive to eutrophication, and can therefore not sustain the same levels of fishing mortality. Furthermore, since both dagaa and haplochromines can be sold in multiple forms (bait, fodder, human consumption), the actual taxonomic content of the dagaa catch has little effect on fishers. Therefore, since the resurgence of haplochromines, the dagaa and haplochromine fisheries and stocks have become tightly connected, which reduces the strength of negative feedbacks and the self-regulating ability of the system (Fig. 3: dagaa fishing effort --o haplochromines versus dagaa fishing effort --o dagaa; haplochromines and dagaa --> LocMar). Indeed, if a reduced stock does not lead to a reduced catch (e.g., should dagaa replace haplochromines, or vice versa), the negative feedback of a dwindling stock on fishers and markets is reduced. This conclusion contrasts the view that selective fisheries-as opposed to balanced harvesting (Garcia et al. 2012)-are detrimental to the ecosystem as a whole. In this particular instance, the lack of selectivity does not equate to a balanced harvesting methodology since it is not adapted to the habitats, life histories, and growth rates of dagaa and haplochromines.

A certain level of nutrient input can increase productivity for one species (enrichment) but represent reduced fitness or increased mortality (eutrophication) for another. Haplochromine species, for example, are particularly sensitive to low light (Seehausen et al. 1997a), whereas dagaa is probably relatively more sensitive to deoxygenation than is Nile perch (Wanink et al. 2001). Without explicit management, nutrient enrichment would most likely always lead to further enrichment-i.e., it is not intrinsically selflimiting or regulating. Enrichment would, however, translate only to increased stock growth until the negative consequences of eutrophication start taking effect and while fishing effort does not cause mortality rates that exceed growth rates (i.e., stock collapse). Ultimately, sustainability of stocks is a function of the relative strength of fishing-induced mortality versus a stock's response in growth through feeding. Since enrichment and eutrophication alter growth rates, sustainable fishing mortality rates must be variable, not constant. Also, although eutrophication affects the whole lake, the distribution and effect of nutrients on the biochemistry of the lake is spatially heterogeneous (Box 3, Table 4). Therefore, the processes that drive growth of stocks - and thus dictate levels of sustainable harvesting - are site-specific and not generalizable across the whole lake at any one time.

Box 3: Spatial heterogeneity of the lake

In inshore areas, terrestrial runoff and detritus are primary sources of light limitation, whereas further offshore it is algal biomass that induces light limitation, and thus restricts photosynthesis to a narrower surface layer. Eutrophication affects the whole lake, as half the total phosphorus input to the lake is from atmospheric deposition (Tamatamah et al. 2005), though there is a lot of spatial heterogeneity in its effects - not only in an inshore-offshore gradient, but also between bays around the lake (Silsbe et al. 2006, Loiselle et al. 2008, Cornelissen et al. 2013). Total nitrogen concentrations have increased since the 1960s, primarily through cyanobacteria fixation, and nitrogen generally follows a decreasing concentration pattern from the coast to offshore waters (Hecky et al. 2010). While nutrient loading has created the light-limited conditions of the lake, seasonal and interannual variations in primary productivity are now driven primarily by climate (Silsbe et al. 2006, Cózar et al. 2012). This is of particular relevance since it highlights an important characteristic of qualitative models such as the one we use: they do not account for time or effect lags (Justus 2005). The synergistic and cumulative effects of warming and eutrophication on phytoplankton and the food web will probably delay the effects of eutrophication management (Schindler 2006).

Increases in nutrients no longer lead to increased phytoplankton primary production in the northern Murchison Bay and Napoleon Gulf of Lake Victoria, indicating that these areas are phosphorus saturated (Silsbe et al. 2006) (Fig. 3: N\&P --> shading). However, recent experiments conducted on samples from the Mwanza Gulf in southern Lake Victoria show that the increase in primary productivity with further nutrient enrichment can still take place (Cornelissen et al. 2013). Effects of further nutrient enrichment are therefore likely to be area- and seasonspecific. Over the years, chlorophyll $a$ measurements have shown a great degree of variability (Table 4). Even though differences in sampling frequency and measurement methods, as well as in location, depth, and timing of sampling make it impossible to draw accurate trends from these data, it appears that chlorophyll concentrations in the northern parts of the lake are higher than in the south (Table 4). 
Table 4. Variability in chlorophyll $a(\mathrm{Chl})$ concentrations in the lake, as found in the literature. Seasons: DS = (dry season): JuneAugust; $\mathrm{SR}=$ (short rains): September-December, LR = (long rains): January-May. $\mathrm{SD}=$ standard deviation. $\mathrm{N}=$ number of measures. LVRO = Lake Victoria Fisheries Organisation.

\begin{tabular}{|c|c|c|c|c|c|c|c|}
\hline Source & Location & Year & Season & Depth $(\mathrm{m})$ & $\mathrm{Chl}(\mu \mathrm{g} / \mathrm{l})$ & $\mathrm{SD}$ & $\mathrm{N}$ \\
\hline \multirow[t]{5}{*}{ Acoustic survey LVFO } & Murchinson Bay & 2005 & DS & $<20$ & 44.6 & & 1 \\
\hline & Mwanza Gulf & 2005 & LR & $<20$ & 18.43 & & 1 \\
\hline & Nyanza Gulf & 2005 & DS & $<20$ & 11.29 & 8.19 & 2 \\
\hline & Nyanza Gulf & 2006 & LR & $<20$ & 8.91 & 2.97 & 4 \\
\hline & Speke Gulf & 2005 & LR & $<20$ & 20.76 & 9.18 & 9 \\
\hline \multirow[t]{3}{*}{ Akiyama et al. (1977) } & Mwanza Gulf & $1973-1974$ & DS & 8 & 4.35 & 1.60 & 6 \\
\hline & Mwanza Gulf & $1973-1974$ & LR & 8 & 5.1 & 2.01 & 6 \\
\hline & Mwanza Gulf & 1973-1974 & SR & 8 & 3.7 & 1.10 & 8 \\
\hline Cózar et al. (2007) & Murchinson & 2003 & DS & $<20$ & 80.92 & 13.73 & 13 \\
\hline Gikuma-Njuru (2008) & Nyanza Gulf & $2005-2006$ & All year & $<20$ & 17.57 & 3.60 & 7 \\
\hline \multirow[t]{3}{*}{ Haande et al. (2011) } & Murchison Bay & 2003-2004 & DS & $<11$ & 21.43 & 6.63 & 14 \\
\hline & Murchison Bay & 2003-2004 & LR & $<11$ & 31.4 & 10.41 & 20 \\
\hline & Murchison Bay & 2003-2004 & SR & $<11$ & 24.06 & 6.54 & 16 \\
\hline Lehman and Branstrator (1993) & Napoleon Gulf & 1992 & SR & $<10$ & 48 & & \\
\hline \multirow{2}{*}{ Lung'Ayia et al. (2000) } & Nyanza Gulf & 1994-1995 & SR & $<10.5$ & 20.77 & 7.48 & 11 \\
\hline & Nyanza Gulf & 1994-1996 & LR & $<10.5$ & 13.45 & 2.77 & 11 \\
\hline \multirow[t]{4}{*}{ Mugidde (2001) } & Napoleon Gulf & 1994-1998 & All year & $<20$ & 71 & 100.4 & 47 \\
\hline & Napoleon Gulf & 1994-1999 & LR & $<20$ & 38.11 & 20.33 & 9 \\
\hline & Napoleon Gulf & 1994-2000 & DS & $<20$ & 27.5 & 18.37 & 6 \\
\hline & Napoleon Gulf & 1994-2001 & SR & $<20$ & 82.5 & 79.94 & 10 \\
\hline \multirow[t]{3}{*}{ Ngupula et al. (2011) } & Tanzania & $2005-2007$ & All year & $<10$ & 16 & 6 & 10 \\
\hline & Tanzania & $2005-2007$ & All year & $10-20$ & 22.5 & 8.5 & 11 \\
\hline & Tanzania & $2005-2007$ & All year & $20-30$ & 11 & 5 & 9 \\
\hline North et al. (2008) & Jinja & $\begin{array}{l}2001-2002- \\
2004\end{array}$ & $\mathrm{SR}$ & $<26$ & 52.9 & 10.60 & 12 \\
\hline \multirow[t]{3}{*}{ Okello et al. (2009) } & Bunjako (Uganda) & 2004 & DS & $<5$ & 9 & 1.41 & 2 \\
\hline & Murchinson Bay & 2004 & DS & $<5$ & 18 & 7.07 & 2 \\
\hline & Napoleon Gulf & 2004 & DS & $<20$ & 10.5 & 0.71 & 2 \\
\hline \multirow[t]{9}{*}{ Shayo et al. (2011) } & Kayenze (Speke Gulf) & 2005 & DS & $<20$ & 14.67 & 7.58 & 6 \\
\hline & Kayenze (Speke Gulf) & 2005 & LR & $<20$ & 18.17 & 3.76 & 6 \\
\hline & Kayenze (Speke Gulf) & 2005 & SR & $<20$ & 13.67 & 6.46 & 9 \\
\hline & Magu (Speke Gulf) & 2005 & DS & $<20$ & 20 & 10.12 & 6 \\
\hline & Magu (Speke Gulf) & 2005 & LR & $<20$ & 18.17 & 12.19 & 6 \\
\hline & Magu (Speke Gulf) & 2005 & SR & $<20$ & 17.56 & 7.21 & 9 \\
\hline & Mwanza Gulf & 2005 & DS & $<20$ & 9.83 & 2.79 & 6 \\
\hline & Mwanza Gulf & 2005 & LR & $<20$ & 13.67 & 4.72 & 6 \\
\hline & Mwanza Gulf & 2005 & SR & $<20$ & 17.56 & 6.17 & 9 \\
\hline \multirow[t]{3}{*}{ Silsbe et al. (2006) } & Fielding & 2001-2002 & DS/SR & $<10$ & 42 & 23.06 & $?$ \\
\hline & Murchison Bay & 2001-2002 & DS/SR & $<8$ & 69.5 & 24.33 & $?$ \\
\hline & Napoleon Gulf & $2001-2003$ & DS/SR & $<14$ & 26 & 6.292 & $?$ \\
\hline \multirow[t]{12}{*}{ Sitoki et al. (2010) } & Whole lake & 2000 & $\mathrm{DS}$ & $<20$ & 12.8 & 11.3 & $?$ \\
\hline & Whole lake & 2000 & LR & $<20$ & 13.2 & 4.4 & $?$ \\
\hline & Whole lake & 2001 & DS & $<20$ & 10.9 & 7 & $?$ \\
\hline & Whole lake & 2001 & LR & $<20$ & 10.8 & 6.7 & $?$ \\
\hline & Whole lake & 2006 & DS & $<20$ & 16.2 & 8 & $?$ \\
\hline & Whole lake & 2006 & LR & $<20$ & 14.8 & 10.9 & $?$ \\
\hline & Whole lake & 2007 & DS & $<20$ & 14.4 & 8.4 & $?$ \\
\hline & Whole lake & 2007 & LR & $<20$ & 15.7 & 8.5 & $?$ \\
\hline & Whole lake & 2008 & DS & $<20$ & 14.5 & 11.2 & $?$ \\
\hline & Whole lake & 2008 & LR & $<20$ & 16.8 & 8.6 & $?$ \\
\hline & Whole lake & 2009 & DS & $<20$ & 14.8 & 6.1 & $?$ \\
\hline & Whole lake & 2009 & LR & $<20$ & 12.7 & 12.5 & $?$ \\
\hline Yasindi and Taylor (2003) & Napoleon Gulf & 1998 & SR & $<15$ & 34 & & \\
\hline \multirow[t]{3}{*}{ Cornelissen et al. (2013) } & Mwanza Gulf & 2009-2011 & DS & $<25$ & 13.24 & 4.71 & 68 \\
\hline & Mwanza Gulf & 2009-2011 & LR & $<25$ & 14.96 & 8.05 & 73 \\
\hline & Mwanza Gulf & 2009-2011 & $\mathrm{SR}$ & $<25$ & 13.45 & 4.60 & 72 \\
\hline
\end{tabular}


Fig. 4. Species and functional diversity loss in the soft-bottom fish community of Lake Victoria. The bars represent the number of haplochromine species per functional group collected in the sublittoral waters $(6-14 \mathrm{~m})$ of the northern part of the Mwanza Gulf, over soft bottom, in 1979-1982 and 20012005. Between 1979-1982 and 2001-2005, 65-70\% of species and $50 \%$ of functional groups were irreversibly lost. One unclassified species is omitted here. Data from Witte et al. (2013). Not only does the number of functional group decrease, but the degree of specialization within trophic groups also decreases: e.g., former zooplanktivores have broader diets in 2001-2005 than in 1979-1982 (Kishe-Machumu 2012, van Rijssel and Witte 2013).

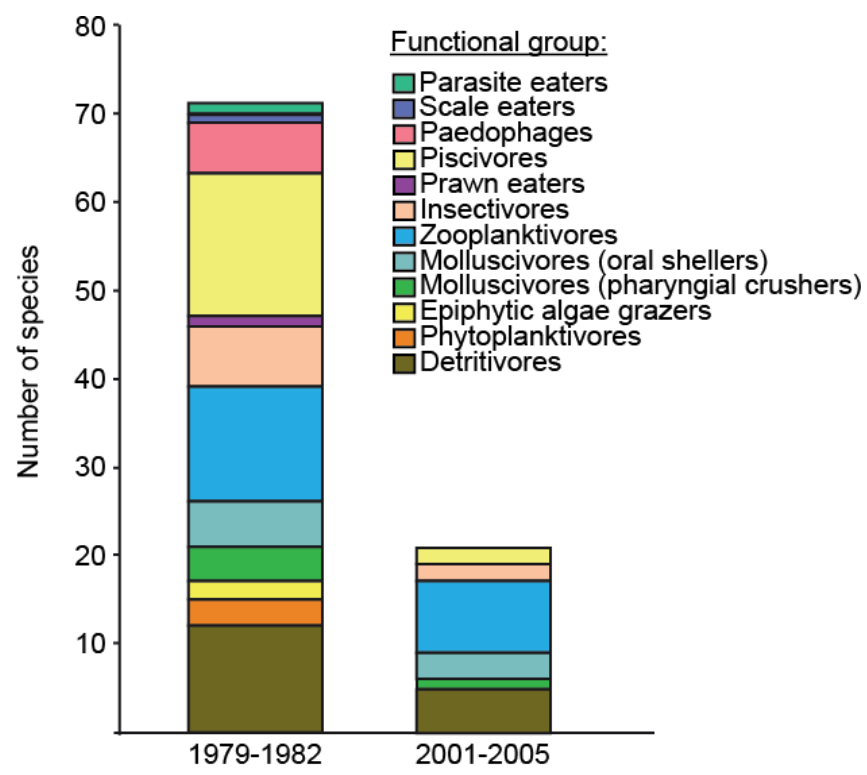

When using the diagrams, it is important to account for underlying assumptions, and to look at different feedback loops in concert. As an example, if nutrient enrichment leads to higher Nile perch stocks (Table 1, row 7), this promotes investment from the international market, which can drive owners to invest effort in alternative stocks, such as dagaa, which would then reduce dagaa stocks. This would thus negatively influence the local and regional market and lead to a decrease in human population growth, which would lead to a decrease in nutrient input. Taken in isolation, such a scenario would be based on questionable assumptions: it would assume that nutrient enrichment has a positive effect only on Nile perch, not on dagaa. It would also assume a single fishery target with no alternative stimuli for the regional market, and that this dynamic is the major determinant of human population growth. This type of loop would represent a case where international economic input does not lead to social and economic growth in the region, and thus does not lead to increased nutrient input to the lake. The diagrams presented here are tools that can enhance understanding and map multiple system variables simultaneously, but even though they are simple tools, their interpretation should not be oversimplified.
Our combined social-ecological diagram allows us to see the effects of change in a broader context, but it has a limited predictive value: indeed, it cannot account for adaptation in either human or fish populations to declines in stock or in environmental conditions. However, with a limited time frame in mind, the diagram can give an idea of the far-reaching effects of any single action on the whole system. We indicated three exogenous stressors: climate change, the international economy, and regional policies. More might exist, and they could have broader effects than illustrated here. These stressors are dubbed exogenous because they are not solely or directly influenced by Lake Victoria's system. Exogenous stressors are important in that they could shift the sign of loops in the feedback diagrams or change the relative importance of any given interaction or loop and thus alter system dynamics.

\section{SYSTEM TRENDS AND CHANGES MATCHED TO THE MODEL}

Here we look into Lake Victoria's past to contextualize the model and identify how its elements and interactions illustrate trends that have shaped the dynamics of the social-ecological system. Through this juxtaposition of model and trends, we can identify the model's scope and limitations and indicate its best uses. Furthermore, it allows us to explore how weights of different interactions might have changed over time.

In the beginning...

Before the introduction of Nile perch, Lake Victoria harbored a small though diverse, multispecies artisanal fishery. Fishing, along with agriculture and livestock herding, constituted the economic foundations of lakeshore societies. The main fishing targets were the native tilapia Oreochromis esculentus and $O$. variabilis (Balirwa et al. 2003, Pringle 2005b). Fish were initially sold by number rather than weight, which invited catches of small fish (Beverton 1959, Balirwa 1998). The introduction of gillnets in the 1920 s as a new tool quadrupled fishing efficiency, and the fishery became commercial - a process further helped by urban infrastructure development (including road and rail) around the lake (Balirwa 1998) (Fig. 3, development of local/regional market: dagaa and haplochromines --> LocMar --> owners and Soc\&econ...).

Since the 1960s, effects of eutrophication-driven by human population growth around the lake and subsequent changes in land use (Verschuren et al. 2002, Hecky et al. 2010)-became apparent. The phytoplankton community underwent a transition from a diatom-dominated community to one increasingly dominated by nitrogen-fixing cyanobacteria, and primary production increased. In turn, the zooplankton community shifted to be dominated by small species (Mwebaza-Ndawula 1994, Gophen et al. 1995, Wanink et al. 2002). The dominance shift in the phytoplankton community has been hypothesized to be a cause in the zooplankton shift (Wanink et al. 2002) (Fig. 1: change in relative importance of phytoplankton --> zooplankton versus phytoplankton --> detritus and anoxia \& shading).

\section{Introduced species, changed ecosystem}

As native stocks were declining from exploitation, eutrophication, and habitat destruction, Nile tilapia (Oreochromis niloticus) and other tilapiine species were introduced. Simultaneously (between 1954 and 1964), Nile perch were introduced to boost the 
productivity of the fisheries and convert the native diversity of haplochromines into a more desirable fishery product (Kudhongania and Chitamwebwa 1995, Pringle 2005b). From 1965, Nile tilapia gradually replaced native tilapia, became a major commercial catch (Balirwa 1998), and is currently an important product for local and regional markets (Njiru et al. 2008). Tilapia does not figure explicitly in our diagrams because it appears to interact little with other stocks (Downing 2012, Downing et al. 2013b). It is, however, of course also influenced by enrichment, eutrophication, and exploitation processes, and contributes to the regional market, and can therefore be read in the system in a similar way to haplochromines or dagaa, but with tilapia-specific sensitivities to the different driving processes.

While the Nile perch introductions had little immediate effect, in the 1980s many changes occurred quite rapidly. Nile perch suddenly became dominant in the whole lake, and - in concert with increased hypoxic and anoxic conditions - contributed to the collapse of haplochromine stocks and mass disappearance or extinction of native fish species (Witte et al. 1992, Hecky et al. 1994, 2010, Verschuren et al. 2002, Goudswaard et al. 2008). The high abundance of haplochromines proved to be favorable for Nile perch as growth estimates in both the Tanzanian and Kenyan waters through the end of the 1980s - covering the time when Nile perch were still feeding heavily on haplochromines - showed that Nile perch grew at least twice as fast as in haplochromine-poor lakes (e.g., Lake Chad, Lake Turkana, Lake Albert, Lake Nasser) (Ligtvoet and Mkumbo 1990) (Fig. 3: Nile perch --o haplochromines). Ecological opportunities afforded by the vanishing haplochromines were exploited in short succession by two native species, first the detritivorous shrimp $C$. nilotica (Goudswaard et al. 2006) and then the zooplanktivorous cyprinid dagaa (R. argentea) (Wanink et al. 2002).

Since the 1990s, effects of eutrophication and fishing have become more apparent, and Lake Victoria's ecosystem is still undergoing many changes. The water hyacinth (Eichhornia crassipes), which first appeared in the lake in 1989 (Chapman et al. 2008), had produced large mats by 1995 . These mats severely interfered with fishing operations, with important social-economic consequences (Opande et al. 2004), and altered the bio-physico-chemical environment of the water under them (Masifwa et al. 2001, Kateregga and Sterner 2008). This event supports the notion that water quality influences stocks and catches, and importantly, that when the lake's environment is compromised in such a way, neither international nor regional markets can act as backups, and society has little (perhaps only agriculture) left to rest on (Fig. 3: N\&P and anoxia \& shading --> Nile perch, dagaa, and haplochromines --> IntMar and LocMar --> Soc\&econ). The hyacinth invasion was in large part managed between 1997 and 1999 through manual removal and the introduction of a weevil (Neochetina eichhorniae). The effects of these management procedures were probably enhanced by an El Niño episode (1997-1998), during which elevated water levels broke off large hyacinth stands, and where low light conditions (clouds) and rain reduced hyacinth growth (Njiru et al. 2002, Williams et al. 2005, 2007, Wilson et al. 2007). Even though the hyacinth bloom was probably triggered by eutrophication, its decline is not a reaction to improved water quality: there are multiple pathways to any single phenomenon.
Dominance of cyanobacteria in the phytoplankton community has led to an increase in concentrations of toxins produced by cyanobacteria (e.g., microcystin). Higher trophic levels - including humans - are increasingly exposed to such toxins, both directly through water and through their accumulation in fish tissues (Poste et al. 2011). Low fish quality would probably reduce fish prices on (or even access to) the international market, but decreased wellbeing or increased illness in lakeshore societies would probably have more complex and further reaching consequences. At this point, however, the extent to which cyanotoxins affect human health around Lake Victoria is unknown, though it is important to keep toxicity in mind as a process in eutrophication.

\section{Societal adaptations}

The advent of the Nile perch boom in the 1980s changed societies dramatically (Fig. 3: IntMar --> owners and Soc\&econ versus LocMar --> owners and Soc\&econ). People migrated to the lakeside to enter the fisheries, which accelerated human population growth and altered the kinship relations that had existed previously. Human populations around the lake continue to grow at a higher rate than the African average (Odada et al. 2009).

Filleting factories were constructed around the lake, and the fish were exported to Europe (Pringle 2005a, Johnson 2010). The major filleting factories were built to process up to 25 tons of Nile perch each, per day, but would break-even on costs when operating at about $30 \%$ capacity (Johnson 2010). Nile perch catches reached a peak in 1990, but effort has continued to increase since.

\section{Changes in dagaa, haplochromines, and the regional market}

Although dagaa is native to Lake Victoria, a directed fishery for it first developed only in the 1960 s. The stocks of dagaa rapidly increased after the Nile perch boom and haplochromine collapse. Dagaa became the lake's second most important fishery by the 1990s (Wanink 1999), when landing sites started organizing themselves into camps, also presenting a strong social structure, from trader to owner, through camp supervisors and laborers, with women drying the fish. Dagaa is currently a dominant commercial fishery of the lake in terms of biomass (Tumwebaze et al. 2007), and it trades on domestic and regional markets (Gibbon 1997). Catch that is successfully dried and cleaned of sand is destined for human consumption as it serves as a cheap source of protein for the poor and middle class (Medard 2012), and the rest sells as animal feed: chicken fodder, for example. Traders play an important role, checking the quality of the product as well as establishing its price (Gibbon 1997). Despite no apparent decrease in its stock size, dagaa has undergone behavioral, morphological, and life history changes in some regions of the lake, which may reflect local adaptive response to predation by Nile perch, fishing pressure, and/or eutrophication and associated hypoxia (Wanink 1999, Wanink and Witte 2000, Manyala and Ojuok 2007, Sharpe et al. 2012). Fishing effort has been on a steady increase (Mkumbo et al. 2007), at least until 2006, from where data suggest a stabilization in effort (Kolding et al. 2014) (Fig. 3: N\&P --> dagaa versus dagga fishing effort --o dagaa). Dagaa remains a product destined mostly for a local and regional market, and is, therefore, less well monitored, regulated, and studied than Nile perch (Medard 2012). 


\section{SOCIAL-ECOLOGICAL CHANGE SEEN IN MODEL STRUCTURE}

The single diagram we developed to represent Lake Victoria's social-ecological system can be used to analyze and represent a whole variety of dynamics. This is necessary because system dynamics have seen both short- and long-term dynamics. Seasons influence light, temperature, weather, and wind conditions, which influence the growth of organisms as well as access to different areas of the lake. Dynamics also have a heterogeneous spatial distribution, considering, for example, the different nutrient environments in the north and south of the lake (Box 3, Table 4), or the atmosphere of conflict in contested Ugandan-Kenyan fish camps (Box 4), or differences in fishing practices (Beuving 2014). All of these factors imply that a quantitative model of Lake Victoria's social-ecological dynamics ought to be set in a clearly defined spatio-temporal setting. Meanwhile, this purely qualitative model allows us to analyze three types of structural changes to the system and their influence on dynamics and role in the effectiveness of policies and regulations: (1) a change in the relative weight of different interactions, (2) the change in the sign of interactions or loops, and (3) the addition or removal of interactions. Here, we analyze - through examples of past changes and hypothetical management policies - the effects of these three types of changes on the dynamics on Lake Victoria's social-ecological system.

Box 4: Societal reorganization and inequity

To ensure constant supply to the factories after the trawling ban became effective in the 1990s (Mbuga et al. 1998), a new socialeconomical interaction emerged: processors invested in building infrastructure to better store Nile perch at landing sites and sponsored fishermen with nets and gear via agents, who would then ensure fixed prices and supply of fish (Mbuga et al. 1998, Geheb et al. 2008, Johnson 2010). Lakeshore societies thus developed a stronger economic hierarchy from processor through agent to fisher, with many fishers then entering a situation of credit towards agents or processors (Geheb et al. 2008). Fishing effort continues to increase and fisher communities to restructure. In the Nile perch fishery in some areas, many agents (middlemen) have become boat owners and landing site or camp managers who employ camp supervisors and laborers to operate full fleets and with whom they arrange credits and loans to ensure a constant fish supply. The structure is likely quite diverse, however, and there are reports of wealthy boat owners striking deals with factories and thus taking a trader's role.

Economic input to society is nonlinear, with larger swaths of income distributed to big owners, and much less reaching fishers and laborers. Besides stocks and the international economy and regulations, local social-economic settings and interactions can have complex effects on both social stability and benefits reapable by owners through fishing. Individual cost-to-benefit ratio of fishing and risk-taking behavior is variable. Competition for landing sites among owners, for example, can influence costs and prices by leading to a local monopoly of the fisheries by few owners. Competition among owners can lead to conflict and violence: there are reports of piracy in the southern part of the lake, which leads to increased costs in security and uneven distribution of fish resources. Also, there are chronic territorial conflicts over fish camp islands between Kenya and Uganda (Otieno 2013). Knowledge of the distribution of power, opportunities, and value of risk in society is key to the selection and implementation of appropriate policy measures. Here, we lack representation of the potential response diversity of society, which is a great impediment to measuring and predicting society's reactions and adaptations to ongoing changes in the system.

\section{Changes to the relative weight of interactions}

Management policies can profoundly influence the connectedness of a system, for example, by creating tighter networks of communication. Increased economic disparity caused an increase in illegal fishing practices in the 1990s. In an effort to improve compliance and better implement fishing regulations, Tanzania established a comanagement approach to the fisheries in 1997, in the form of Beach Management Units (BMUs) (Kateka 2010). These local groups were established to increase stakeholder participation in surveillance and management of the fisheries, and similar structures were later implemented in Uganda and Kenya (Mkumbo 2002, Kateka 2010). Their success has been mixed, however: BMUs have effectively suppressed poisoning and dynamiting as fishing techniques, but they lack an adequate legal status, and by establishing their own bylaws, BMUs can sometimes abuse their position and authority (Geheb et al. 2007, Njiru et al. 2007). Importantly, they have also increased fishing efficiency through improving communication networks (Eggert and Lokina 2009) (Fig. 3: strengthening of interactions Nile perch and dagaa fishing effort has a negative effect on Nile perch, dagaa, and haplochromines), helping fishers get to good fishing sites faster and reducing the negative feedback of declining stocks on fishers.

\section{Changes in the sign of interactions or feedbacks}

Fertilizer subsidies, which might promote agriculture and alternative sources of income, would nonetheless reinforce positive feedback loops through nutrient enrichment, and thus be overall destabilizing. A fishing limiting policy, such as a licencing fee, could add a minus to fishing effort and change the signs of the loops in that way, though if it is not applied to all fisheries, such a policy could have a backlash effect and lead to higher exploitation of alternative fisheries or to increased land use for agriculture. In short, the effect of any single policy or change depends on its ripple effects through the broader system.

\section{Changing the number of pathways in the system}

In a bid to prevent and eliminate illegal, unregulated, and unreported fishing, the Lake Victoria Fisheries Organisation has pushed to promote eco-labeling of Nile perch. For this, they established codes of practice with help from the Marine Stewardship Council (Kolding et al. 2014). In 2009, the German cooperative Naturland launched its eco-label for the small capture Nile perch fishery, certifying the sustainability of Nile perch products exported to Germany. The label is based on ecosystem, fishery, social, and hygiene criteria, and covers eight landing sites and 1000 fishermen in Tanzania (Bukoba), though there is currently no known study that evaluates the effects of eco-labeling on the stocks, society, or economy. However, seen through our diagram, Naturland's policy-i.e., supporting a small-scale 
fishery on the Nile perch — might be translated by adding a role to some owners, whereby their connection between the regional market and the Nile perch fishery is subject to regulations (Fig. 3: LocMar --> owners --> Nile perch fishing effort) and where owners connect the regional and international market (Fig. 3, IntMar --> owners --> LocMar). One of the loops that would then emerge is a negative feedback loop connecting the regional market to fisheries, Nile perch stocks, the international market, local societies, and the regional market (Fig. 3: LocMar --> owners --> Nile perch fishing effort --o Nile perch --> IntMar --> Soc\&econ (or owners) --> LocMar). This constraint on the middleman (owner) would differ from the loops we have so far accounted for in that the owner's role merges with that of the local and regional economy and society (Fig. 3, Soc\&econ). Such a loop might have beneficial social-economic repercussions since it could reduce economic disparity (note that we separated owners from society to be able to reflect differences in economic benefits and incentives). However, in itself, this policy still only adds a pathway to harvesting Nile perch: a small-scale fishery might be sustainable if taken on its own, but as long as it operates in parallel with other harvesting policies, the stocks might yet be vulnerable to unsustainable harvesting. Therefore, for a policy like that of Naturland to actually ensure sustainable Nile perch harvesting, it needs to outcompete existing harvesting strategies (effectively connecting itself to other fisheries with a minus sign in our diagram). While not all owners are party to the policy, sustainable harvesting might happen if the label succeeds in influencing consumption patterns in the international market (and) or if different incentives to harvest sustainably are presented directly to fishermen and fishing site owners.

\section{Quantitative versus structural changes to the system}

Overall, we find that policies and changes that alter the connectedness of the system influence the self-regulatory capacity of the system. Connection strength changes are probably the most common and insidious changes in the system, as they can be an uncalculated side effect of various other policies (as for example, the case of BMUs). Also, given the heterogeneity in conditions and processes over the whole lake, differences in connectedness across the system influence the generalizability of policy interventions: interaction strengths are not the same across the whole lake or even permanent in time (Boxes 2 and 3). Changes in the sign and number of interactions, however, as for example the Naturland eco-labeling policy, can alter system dynamics without necessarily altering the integrity of regulating feedback mechanisms, though the effects of such structural changes are dependent on the configuration and dynamics of the system as a whole.

\section{DISCUSSION}

Here, we put together pieces of Lake Victoria's social-ecological system in a qualitative, conceptual model and achieve greater understanding of the system's functioning from a good prior knowledge of the processes behind dynamics, as well as from the key elements and interactions that are specific to Lake Victoria.

The interconnection diagram highlights the multiple pathways to any single phenomenon in the system. As an example, the threat to fisheries stems not only from fishing effort but also from other environmental factors: eutrophication, hypoxia, and anoxia reduce fish growth and survival rates, thereby increasing the stocks' vulnerability to fishing pressure. Complete overharvesting of Lake Victoria's fishes, be it Nile perch, dagaa, or tilapia, would not necessarily be an easy task: the number of fishers and crafts on the lake has increased dramatically since the early 1990s, but technologies have not followed suit everywhere. Paddling is still the dominant method of propulsion in a large part of the lake, and where engines are available, fuel costs, and in the case of the Nile perch fishery, costs related to the hygienic storage of fish during longer periods, as well as dangerous boating conditions, all impose limits on the distance from shore that is exploited. Dagaa is also difficult to harvest efficiently, despite being a productive species: fishing of dagaa occurs mostly on moonless, windless nights, using lamps that attract insects and zooplankton and then the zooplanktivores, including dagaa. However, even if all stocks are not currently overfished, the threat to Lake Victoria's fisheries is real. Indeed, native tilapia (ngege [Oreochromis esculentus]) was successfully reduced to low numbers using quite simple methods before the introduction of Nile perch and Nile tilapia. Even though the dagaa fishery might not be the most important direct threat to dagaa stocks, it could be an important influence on haplochromines since the two fisheries are connected through fishing methods and markets. The adaptability of fishers and markets to changes in stocks might reduce the self-regulating character of exploitation (i.e., dampen the negative feedback of exploitation loops) and make a stock collapse even less predictable or even avoidable. In this way, while overfishing is not necessarily currently the biggest threat to fisheries on Lake Victoria per se, it becomes an important threat in the presence of environmental change and eutrophication, and in the context of the full, interconnected system.

Interestingly, here we find that even though high connectivity of fisheries at the level of owners and markets may be detrimental to stocks (Box 2), it can also make the social-economic system more robust to the loss of the international market. A loss of the international market would cause a dramatic loss of revenue, but there is no shortage of demand for fish products, in general, and fishing markets have diversified. Dagaa, haplochromines, and small Nile perch are sold locally and regionally for human consumption and as animal feed. Tilapia and Nile perch fetch higher prices on the same markets. Furthermore, a shutdown of all international trade is considered highly unlikely. In the same way as when the European market closed in 1997, Israel and Asia and other African countries could perhaps serve as alternative markets (van der Knaap et al. 2002). Nonetheless, it is important to remember that lakeshore societies have grown and developed fast, and a lack of long-term investments or permanent structures contributes to the high and increasing income disparity in lakeshore populations, which in turn can influence societies and contribute to their increased volatility (Wilkinson and Pickett 2009).

The rapid Nile perch invasion created a strong dependence on fisheries (as exemplified during the water hyacinth blooms), which probably makes societies quite vulnerable to a loss of stocks, especially since there are few other sources of steady income. Indeed, as the Nile perch fishery grew, migrant settlements that started off as temporary became villages - with bars, makeshift cinema halls, and brothels - though they often lack essential 
permanent structures such as medical units or schools (Geheb et al. 2008). Investment opportunities lie mostly in high profit margin activities rather than in durable or saving schemes, the economic life is deeply monetized since there is little selfsustenance, and most goods must be bought (Beuving 2010). People in these boom villages easily fall into a poverty trap. General health status is low, and there is a high HIV-AIDS infection and prevalence rate (van der Knaap and Ligtvoet 2010). Therefore, alternative sources of income are undoubtedly highly dependent on the fisheries - the services sold in villages and camps are targeted at fishers. These will not provide a safety net should fisheries collapse. Agriculture, chicken farming, and livestock herding are among the few sources of income that are independent of fisheries. Following this analysis, we suggest new metrics with which to bridge social and ecological changes in future studies: investments in infrastructure and the sources of these investments might provide a usable proxy for the dependence of societies on their resources. Such data might also inform the sustainability or durability of development around Lake Victoria. While investment in urban and transport infrastructure in the early 20th century and in fish processing infrastructures in the 1980s heralded priority areas of future development around the lake, there was no comparable spending on agricultural infrastructure.

This model does not yet encompass the full complexity of Lake Victoria's societal components (e.g., Box 4). We lacked the references and detail needed to generalize the different processes that drive societal dynamics, and how these induce individuals to take risks, drive investment, and frame decision-making processes. In short, our model strongly underrepresents the response diversity of society (all those processes hidden in the feedback between society and the local market). In the same way, our model lacks resolution in terms of biodiversity (Box 5). We can represent functional diversity to a small degree-which underlies in part the haplochromine-dagaa interrelation-but the full biodiversity and richness of the ecosystem, which sets the stage for the adaptability of the system to changes and disturbances, is not represented. These two elementsbiodiversity and social structure - are directly relevant to any medium-term predictions on system dynamics, to policy-making, and to the assessment of the social-ecological system's current state. Also, it is important to remind the reader that the ecosystem we describe has a strong aquatic bias. In truth, any visitor to the lake will first encounter a large diversity of birds, insects, and vegetation, all of which influence and are influenced by changes in the aquatic, terrestrial, climatic, and human systems. This, however, is at least a first step in bridging the socialeconomic-(aquatic)-ecosystem, in hopes that encouraging further work on bridges to avian and terrestrial ecology might be possible in the future.

Box 5: Diversity changes

Even though the resurging offshore haplochromine community has largely recovered in biomass and retained a 40-strong species diversity (Seehausen et al. 1997b), of which 15-20 species are pelagic, this is only a small fraction of the 1970s haplochromine diversity. Indeed, $65-70 \%$ of both benthic and pelagic species dwelling over soft bottoms in the sublittoral waters (6-14 m deep) of the Mwanza Gulf seem to have been irreversibly lost (Kishe-
Machumu 2012, Witte et al. 2013) (Fig. 4). In the pre-Nile perch system, an estimated minimum of 500 different species of haplochromines occupied almost every function in the food web, from detritivorous species through to piscivores. Fishing pressure on Nile perch (Fig. 3: Nile perch fishing effort --o Nile perch --o haplochromines), as well as morphological adaptations to changed environmental conditions and major habitat shifts are possibly associated with the reappearance of haplochromines (Kitchell et al. 1997, Seehausen et al. 1997b, Schindler et al. 1998, Witte et al. 2000, 2008, Balirwa et al. 2003, Mkumbo and Mlaponi 2007, van Rijssel and Witte 2013). Dominant haplochromines of the Mwanza Gulf in 2006-2008 and 2010-2011 were found to be predominantly the former zooplanktivores and detritivores/ phytoplanktivores (Kishe-Machumu 2012). However, diets of haplochromine species recovering since the 1990s changed: they contained more macro-invertebrates than in the 1970s and early 1980s (Kishe-Machumu et al. 2008). Although in recent years haplochromines seem to have reverted to zooplanktivory, they are less specialized than they were in the 1970s and 1980s (KisheMachumu 2012, van Rijssel and Witte 2013).

In our feedback diagrams, we linked all fields of research at their boundaries, thus shifting the focus from each field's central themes to the interconnections between fields. The diagrams show how a change in any part of Lake Victoria's system can trigger chain reactions across the system. Many of these chain reactions contain or are part of feedback loops, indicating that changes in the system can initiate and drive new dynamic regimes. By analyzing this interconnected system, we find multiple pathways to what may at first appear to be singular, linear phenomena. The presence of multiple pathways can be dangerous since it can lead to a misinterpretation of mechanisms driving change, but it can also be advantageous: by understanding different pathways that regulate a single process, we obtain multiple tools with which to manage change.

We investigate the mechanisms of change through the socialecological model. Changes to the structure of the system, which can be brought about through evolution and adaptation in the social-ecological system (for example, a broadening of a species' diet creating a new interaction, a species extinction leading to a loss of an interaction, or technical or cultural changes in the social system) or through the implementation of policies, can dramatically alter systems dynamics and responses to change. Though our analysis is not quantitative, we can nonetheless see that differences in relative strengths of interactions, which can be understood as a change in the system state, can greatly influence the vulnerability of system elements to further change. Such quantitative changes and differences can be quite pervasive in both time and space. The dominant processes shaping the Lake Victoria's dynamics have changed over time and are heterogeneous in space. This heterogeneity implies that multiple system states exist, which means on the one hand that studies on any part of the system must be understood in their specific spacetime context, and on the other hand that the scope of management actions must be scale adapted.

The system's heterogeneity can also explain some of the scientific disagreement that prevails regarding the state of the fisheries. 
Efforts ought to be made to determine the spatio-temporal scales at which different processes dominate. Lake Victoria's complex, changing, and interconnected system calls for an adaptive management approach capable of embracing this heterogeneity. Adaptive management requires in large part that stakeholders have a common understanding and knowledge of their system (Ostrom 2009). By combining knowledge from different fields and perspectives, we tried to develop such common knowledge. This knowledge should not be interpreted as absolute. Rather, it will wax and develop as users and scientists learn from further changes in Lake Victoria's system and from the system's responses to management. Choices of management policies need not and will not wait for more or better knowledge of the system's dynamics: they are part of the learning processes.

This little history of Lake Victoria highlights how nearly all regulations or policies that have been put in place in Lake Victoria have only ever targeted fishing. Almost nothing has been done to halt or reverse eutrophication. In part, this is because the main sources of eutrophication - i.e., land burning - have only recently been defined. Though eutrophication already displayed effects in the 1960s, it has only recently been acknowledged as a potential and in fact important driver of change in Lake Victoria's system. Indeed, this is to our knowledge the first interdisciplinary study to put eutrophication and fisheries in Lake Victoria on an equal footing, and perhaps in this way signals a turning point in the understanding of drivers of change in Lake Victoria. Eutrophication is ongoing, has damaging consequences for Lake Victoria's system, cannot compensate for or be remediated by fishery policies, and must be addressed for the general health of the system, its users, and fisheries. Additionally, any fisheryoriented policy is likely to be ineffective in the absence of a parallel eutrophication and broader lake basin management policy. Associated policy options must be processed and understood by societies to be made operational, yet we still lack a lot of knowledge about social dynamics and interactions. Furthermore, biodiversity is likely to be key in helping to process excess nutrients, restore better water quality, and value and enjoy the host of nonfishery-related ecosystem services that the lake also provides. The full role of biological diversity and its potential to recover in Lake Victoria are largely unknown. Our study points to society and diversity as two key subjects Lake Victoria scientists need to unravel.

Responses to this article can be read online at: http://www.ecologyandsociety.org/issues/responses. php/6965

\section{Acknowledgments:}

We would like to thank Koos Vijverberg for his very constructive comments on the manuscript. Many thanks to Tijs Goldschmidt and the Artis-bibliotheek for hosting interesting debates on Lake Victoria. This work is part of the integrated project "Exploitation or eutrophication as threats for fisheries? Disentangling social and ecological drivers of ecosystem changes in Lake Victoria (SEDEC)," supported by the Netherlands Organisation for Scientific Research (NWO/WOTRO) grant number W01.65.304.00.

\section{LITERATURE CITED}

Abila, R. O., and E. G. Jansen. 1997. From local to global markets. The fish exporting and fishmeal industries of Lake Victoriastructure, strategies and socio-economic impacts in Kenya. IUCN, Nairobi, Kenya.

Akiyama, T., A. A. Kajumulo, and S. Olsen. 1977. Seasonal variations of plankton and physico-chemical condition in Mwanza Gulf, Lake Victoria. Bulletin of Freshwater Fisheries Research Laboratory 27:49-61.

Awange, J. L., and O. Ong'ang'a. 2006. Lake Victoria, ecology, resources, environment. Springer, Victoria.

Balirwa, J. S. 1998. Lake Victoria wetlands and the ecology of the Nile tilapia, Oreochromis niloticus Linne. Dissertation, Wageningen University, Balkema, Rotterdam, The Netherlands.

Balirwa, J. S., C. A. Chapman, L. J. Chapman, I. G. Cowx, K. Geheb, L. Kaufman, R. H. Lowe-McConnell, O. Seehausen, J. H. Wanink, R. L. Welcomme, and F. Witte. 2003. Biodiversity and fishery sustainability in the Lake Victoria basin: an unexpected marriage? BioScience 53:703-715. http://dx.doi. org/10.1641/0006-3568(2003)053[0703:BAFSIT]2.0.CO;2

Beuving, J. J. 2010. Playing pool along the shores of Lake Victoria. Fishermen, careers and capital accumulation in the Ugandan Nile perch business. Journal of the International African Institute (Africa) 80:1-27.

Beuving, J. 2013. Chequered fortunes in global exports: the sociogenesis of African entrepreneurship in the Nile perch business at Lake Victoria, Uganda. European Journal of Development Research 25:501-517. http://dx.doi.org/10.1057/ ejdr.2013.28

Beuving, J. 2014. Spatial diversity in small-scale fishing: a sociocultural interpretation of the Nile perch sector on Lake Victoria, Uganda. Tijdschrift voor economische en sociale geografie. http:// dx.doi.org/10.1111/tesg.12081

Beverton, R. J. H. 1959. A report on the state of Lake Victoria fisheries. Mimeo, Fisheries Laboratory, Lowestoft.

Chapman, L. J., C. A. Chapman, L. Kaufman, F. Witte, and J. Balirwa. 2008. Biodiversity conservation in African inland waters: lessons of the Lake Victoria region. Verhandlungen des Internationalen Verein Limnologie 30:16-34.

Cornelissen, I. J. M., G. M. Silsbe, J. A. J. Verreth, E. van Donk, and L. A. J. Nagelkerke. 2013. Dynamics and limitations of phytoplankton biomass along a gradient in Mwanza Gulf, southern Lake Victoria (Tanzania). Freshwater Biology 59:127141. http://dx.doi.org/10.1111/fwb.12253

Cózar, A., N. Bergamino, S. Mazzuoli, N. Azza, L. Bracchini, A. M. Dattilo, and S. A. Loiselle. 2007. Relationships between wetland ecotones and inshore water quality in the Ugandan coast of Lake Victoria. Wetlands Ecology and Management 15:499-507. http://dx.doi.org/10.1007/s11273-007-9046-6

Cózar, A., M. Bruno, N. Bergamino, B. Úbeda, L. Bracchini, A. M. Dattilo, and S. A. Loiselle. 2012. Basin-scale control on the phytoplankton biomass in Lake Victoria, Africa. PloS ONE 7: e29962. http://dx.doi.org/10.1371/journal.pone.0029962 
Dobiesz, N. E., R. E. Hecky, T. B. Johnson, J. Sarvala, J. M. Dettmers, M. Lehtiniemi, L. G. Rudstam, C. P. Madenjian, and F. Witte. 2010. Metrics of ecosystem status for large aquatic systems - a global comparison. Journal of Great Lakes Research 36:123-138. http://dx.doi.org/10.1016/j.jglr.2009.11.003

Downing, A. S. 2012. Seeing the water for the fish: building on perspectives of Lake Victoria. Dissertation, Wageningen University, The Netherlands.

Downing, A. S., N. Galic, K. P. C. Goudswaard, E. H. van Nes, M. Scheffer, F. Witte, and W. M. Mooij. 2013a. Was Lates late? A null model for the Nile perch boom in Lake Victoria. PloS ONE 8:e76847. http://dx.doi.org/10.1371/journal.pone.0076847

Downing, A. S., E. H. van Nes, J. H. Janse, F. Witte, I. J. M. Cornelissen, M. Scheffer, and W. M. Mooij. 2013b. Assembling the pieces of Lake Victoria's many food webs: Reply to Kolding. Ecological Applications 23:671-675. http://dx.doi.org/10.1890/12-1418.1

Downing, A. S., E. H. van Nes, J. H. Janse, F. Witte, I. J. M. Cornelissen, M. Scheffer, and W. M. Mooij. 2012a. Collapse and reorganization of a food web of Mwanza Gulf, Lake Victoria. Ecological Applications 22:229-239. http://dx.doi.org/10.1890/11-0941.1

Downing, A. S., E. H. van Nes, W. M. Mooij, and M. Scheffer. $2012 b$. The resilience and resistance of an ecosystem to a collapse of diversity. PloS ONE 7:e46135. http://dx.doi.org/10.1371/ journal.pone.0046135

Downing, A. S., E. H. van Nes, K. E. van de Wolfshaar, M. Scheffer, and W. M. Mooij. 2013c. Effects of resources and mortality on the growth and reproduction of Nile perch in Lake Victoria. Freshwater Biology 58:828-840. http://dx.doi. org/10.1111/fwb.12089

Eggert, H., and R. B. Lokina. 2009. Regulatory compliance in Lake Victoria fisheries. Environment and Development Economics 15:197.

Garcia, S. M., J. Kolding, J. Rice, M.-J. Rochet, S. Zhou, T. Arimoto, J. E. Beyer, L. Borges, A. Bundy, D. Dunn, E. A. Fulton, M. Hall, M. Heino, R. Law, M. Makino, A. D. Rijnsdorp, F. Simard, and A. D. M. Smith. 2012. Reconsidering the consequences of selective fisheries. Science 335:1045-1047. http:// dx.doi.org/10.1126/science.1214594

Geheb, K., S. Kalloch, M. Medard, A.-T. Nyapendi, C. Lwenya, and M. Kyangwa. 2008. Nile perch and the hungry of Lake Victoria: gender, status and food in an East African fishery. Food Policy 33:85-98. http://dx.doi.org/10.1016/i.foodpol.2007.06.001

Geheb, K., M. Medard, M. Kyangwa, and C. Lwenya. 2007. The future of change: roles, dynamics and functions for fishing communities in the management of Lake Victoria's fisheries. Aquatic Ecosystem Health \& Management 10:467-480. http://dx. doi.org/10.1080/14634980701704098

Gibbon, P. 1997. "The poor relation. A political economy of the marketing chain for dagaa in Tanzania." Pages 1-67 in CDR Working Paper 97.2, Center for Development Research, Copenhagen, Denmark.

Gikuma-Njuru, P. 2008. Physical and biogeochemical gradients and exchange processes in Nyanza Gulf and main Lake Victoria
(East Africa). Dissertation, University of Waterloo, Waterloo, Ontario, Canada.

Gophen, M., P. B. O. Ochumba, and L. S. Kaufman. 1995. Some aspects of perturbation in the structure and biodiversity of the ecosystem of Lake Victoria (East Africa). Aquatic Living Resources 8:27-41. http://dx.doi.org/10.1051/alr:1995003

Goudswaard, K. P. C., F. Witte, and E. F. B. Katunzi. 2008. The invasion of an introduced predator, Nile perch (Lates niloticus, L.) in Lake Victoria (East Africa): chronology and causes. Environmental Biology of Fishes 81:127-139. http://dx.doi. org/10.1007/s10641-006-9180-7

Goudswaard, K. P. C., F. Witte, and J. H. Wanink. 2006. The shrimp Caridina nilotica in Lake Victoria (East Africa), before and after the Nile perch increase. Hydrobiologia 563:31-44. http:// dx.doi.org/10.1007/s10750-005-1385-9

Haande, S., T. Rohrlack, R. P. Semyalo, P. Brettum, B. Edvardsen, A. Lyche-Solheim, K. Sørensen, and P. Larsson. 2011. Phytoplankton dynamics and cyanobacterial dominance in Murchison Bay of Lake Victoria (Uganda) in relation to environmental conditions. Limnologica 41:20-29. http://dx.doi. org/10.1016/j.limno.2010.04.001

Hecky, R. E., H. A. Bootsma, and E. O. Odada. 2006. African lake management initiatives: the global connection. Lakes \& Reservoirs: Research \& Management 11:203-213. http://dx.doi. org/10.1111/j.1440-1770.2006.00307.x

Hecky, R. E., F. W. B. Bugenyi, P. Ochumba, J. F. Talling, R. Mugidde, M. Gophen, and L. Kaufman. 1994. Deoxygenation of the deep water of Lake Victoria, East Africa. Limnology and Oceanography 39:1476-1481. http://dx.doi.org/10.4319/10.1994.39.6.1476

Hecky, R. E., R. Mugidde, P. S. Ramlal, M. R. Talbot, and G. W. Kling. 2010. Multiple stressors cause rapid ecosystem change in Lake Victoria. Freshwater Biology 55:19-42. http://dx.doi. org/10.1111/j.1365-2427.2009.02374.x

Johnson, J. L. 2010. From Mfangano to Madrid: the global commodity chain for Kenyan Nile perch. Aquatic Ecosystem Health \& Management 13:20-27. http://dx.doi.org/10.1080/1463$\underline{4980903584694}$

Justus, J. 2005. Qualitative scientific modeling and loop analysis Philosophy of Science 72:1272-1286. http://dx.doi.org/10.1086/508099

Kambewa, E. V. 2007. Balancing the people, profit and planet dimensions in international marketing channels. A study on coordinating mechanisms in the Nile perch channel from Lake Victoria. Wageningen University, The Netherlands.

Kateka, A. G. 2010. Co-management challenges in the Lake Victoria fisheries. Stockholm University, Stockholm, Sweden.

Kateregga, E., and T. Sterner. 2008. Lake Victoria fish stocks and the effects of water hyacinths on the catchability of fish. Pages $1-$ 28 in Environment for Development Discussion Paper Series.

Katunzi, E. F. B., W. L. T. Van Densen, J. H. Wanink, and F. Witte. 2006. Spatial and seasonal patterns in the feeding habits of juvenile Latesniloticus (L.), in the Mwanza Gulf of Lake Victoria. Hydrobiologia 568:121-133. http://dx.doi.org/10.1007/s10750-006-0033-3 
Katunzi, E. F. B., J. Zoutendijk, T. Goldschmidt, J. H. Wanink, and F. Witte. 2003. Lost zooplanktivorous cichlid from Lake Victoria reappears with a new trade. Ecology of Freshwater Fish 12:237-240. http://dx.doi.org/10.1046/j.1600-0633.2003.00023.x

Kayanda, R., A. M. Taabu, R. Tumwebaze, L. Muhoozi, T. Jembe, E. Mlaponi, and P. Nzungi. 2009. Status of the major commercial fish stocks and proposed species-specific management plans for Lake Victoria. African Journal of Tropical Hydrobiology and Fisheries 21:15-21.

Kishe-Machumu, M. A. 2012. Inter-guild differences and possible causes of the recovery of cichlid species in Lake Victoria, Tanzania. Dissertation, Leiden University, Leiden, The Netherlands.

Kishe-Machumu, M., F. Witte, and J. H. Wanink. 2008. Dietary shift in benthivorous cichlids after the ecological changes in Lake Victoria. Animal Biology 58:401-417. http://dx.doi. org/10.1163/157075608X383700

Kishe-Machumu, M. A., F. Witte, J. H. Wanink, and E. F. B. Katunzi. 2012. The diet of Nile perch, Lates niloticus (L.) after resurgence of haplochromine cichlids in the Mwanza Gulf of Lake Victoria. Hydrobiologia 682:111-119. http://dx.doi. org/10.1007/s10750-011-0822-1

Kitchell, J. F., D. E. Schindler, R. Ogutu-Ohwayo, and P. N. Reinthal. 1997. The Nile perch in Lake Victoria: interactions between predation and fisheries. Ecological Applications 7:653664. http://dx.doi.org/10.1890/1051-0761(1997)007[0653:TNPILV] 2.0.CO;2

Kolding, J. 1993. Population dynamics and life-history styles of Nile tilapia, Oreochromis niloticus, in Ferguson's Gulf, Lake Turkana, Kenya. Environmental Biology of Fishes 37:25-46. http://dx.doi.org/10.1007/BF00000710

Kolding, J., M. Medard, O. Mkumbo, and P. A. M. van Zwieten. 2014. Status, trends and management of the Lake Victoria fisheries. In R. L. Welcomme, J. Valbo-Jørgensen, and A. S. Halls, editors. Inland fisheries evolution and management - case studies from four continents. FAO Fisheries and Aquaculture Technical Paper 579. In press.

Kolding, J., P. van Zwieten, O. Mkumbo, G. Silsbe, and R. Hecky. 2008. Are the Lake Victoria fisheries threatened by exploitation or eutrophication? Towards an ecosystem-based approach to management. Pages 309-354 in G. Bianchi and H. R. Skjoldal, editors. The ecosystem approach to fisheries. http://dx.doi. org/10.1079/9781845934149.0309

Kudhongania, A. W., and D. B. R. Chitamwebwa. 1995. Impact of environmental change, species introductions and ecological interactions on the fish stocks of Lake Victoria. Pages 19-32 in T. J. Pitcher and P. J. B. Hart, editors. The impact of species changes in African Lakes. Chapman \& Hall, London, UK. http://dx.doi. org/10.1007/978-94-011-0563-7 2

Lehman, J. T., and D. K. Branstrator. 1993. Effects of nutrients and grazing on the phytoplankton of Lake Victoria. Verhandlungen der internationale Vereinigung für Limnologie 25:850-855.

Levins, R. 1974. The qualitative analysis of partially specified systems. Annals of the New York Academy of Sciences 231:123138. http://dx.doi.org/10.1111/j.1749-6632.1974.tb20562.x
Ligtvoet, W., and O. C. Mkumbo. 1990. Synopsis of ecological and fishery research on Nile perch (Lates niloticus) in Lake Victoria, conducted by HEST/TAFIRI in Report of the fifth session of the sub-committee for the development and management of the fisheries of Lake Victoria. Pages 35-74 FAO Fisheries Report 430. Rome, Italy.

Loiselle, S. A., N. Azza, A. Cózar, L. Bracchini, A. Tognazzi, A. Dattilo, and C. Rossi. 2008. Variability in factors causing light attenuation in Lake Victoria. Freshwater Biology 53:535-545. http://dx.doi.org/10.1111/j.1365-2427.2007.01918.x

Lung'Ayia, H. B. O., A. M'Harzi, M. Tackx, J. Gichuki, and J. J. Symoens. 2000. Phytoplankton community structure and environment in the Kenyan waters of Lake Victoria. Freshwater Biology 43:529-543. http://dx.doi.org/10.1046/j.1365-2427.2000. t01-1-00525.x

Manyala, J. O., and J. E. Ojuok. 2007. Survival of the Lake Victoria Rastrineobola argentea in a rapidly changing environment: biotic and abiotic interactions. Aquatic Ecosystem Health \& Management 10:407-415. http://dx.doi. org/10.1080/14634980701704155

Masifwa, W. F., T. Twongo, and P. Denny. 2001. The impact of water hyacinth, Eichhornia crassipes (Mart) Solms on the abundance and diversity of aquatic macroinvertebrates along the shores of northern Lake Victoria, Uganda. Hydrobiologia 452:79-88. http://dx.doi.org/10.1023/A:1011923926911

Mbuga, J. S., A. Getabu, A. Asila, M. Medard, and R. Abila. 1998. Trawling in Lake Victoria: its history, status and effects. Socio-economics of the Lake Victoria Fisheries Project Report No. 3. IUCN, Nairobi, Kenya.

Medard, M. 2012. Relations between people, relations about things: gendered investment and the case of the Lake Victoria fishery, Tanzania. Signs 37:555-566. http://dx.doi.org/10.1086/662704

Mkumbo, O. C. 2002. Assessment and management of Nile perch (Lates niloticus L.) stocks in the Tanzanian waters of Lake Victoria. Dissertation, University of Hull, Hull, UK.

Mkumbo, O. C., and E. Mlaponi. 2007. Impact of the baited hook fishery on the recovering endemic fish species in Lake Victoria. Aquatic Ecosystem Health \& Management 10:458-466. http://dx. doi.org/10.1080/14634980701704197

Mkumbo, O. C., P. Nsinda, C. N. Ezekiel, I. G. Cowx, and M. Aeron. 2007. Towards sustainable exploitation of Nile perch consequential to regulated fisheries in Lake Victoria. Aquatic Ecosystem Health \& Management 10:449-457. http://dx.doi. org/10.1080/14634980701708057

Mugidde, R. 2001. Nutrient status and planktonic nitrogen fixation in Lake Victoria. Dissertation, University of Waterloo, Waterloo, Ontario, Canada.

Muhoozi, L. I. 2002. Exploitation and management of the artisanal fisheries in the Ugandan waters of Lake Victoria. Dissertation, University of Hull, Hull, UK.

Mwebaza-Ndawula, L. 1994. Changes in relative abundance of zooplankton in northern Lake Victoria, East Africa. Hydrobiologia 272:259-264. http://dx.doi.org/10.1007/BF00006526 
Ngupula, G. W., A. S. E. Mbonde, and C. N. Ezekiel. 2011. Spatial and temporal patterns of phytoplankton abundance and composition in three ecological zones in the Tanzanian waters of Lake Victoria. African Journal of Aquatic Science 36:197-206. http://dx.doi.org/10.2989/16085914.2011.589118

Ngupula, G. W., and E. Mlaponi. 2010. Changes in abundance of Nile shrimp, Caridina nilotica (Roux) following the decline of Nile perch and recovery of native haplochromine fishes, Lake Victoria, Tanzanian waters. Aquatic Ecosystem Health \& Management 13:196-202. http://dx.doi.org/10.1080/14634988.2$\underline{010.483188}$

Njiru, M., P. Nzungi, A. Getabu, E. Wakwabi, A. Othina, T. Jembe, and S. Wekesa. 2007. Are fisheries management, measures in Lake Victoria successful? The case of Nile perch and Nile tilapia fishery. African Journal of Ecology 45:315-323. http://dx.doi. org/10.1111/j.1365-2028.2006.00712.X

Njiru, M., J. Ojuok, a. Getabu, T. Jembe, M. Owili, and C. Ngugi. 2008. Increasing dominance of Nile tilapia, Oreochromis niloticus (L) in Lake Victoria, Kenya: consequences for the Nile perch Lates niloticus (L) fishery. Aquatic Ecosystem Health \& Management 11:42-49. http://dx.doi.org/10.1080/14634980701878090

Otieno, E. 2013. Kenya and Uganda clash over Migingo. Daily Nation, Monday, July 1. 2013. http://www.nation.co.ke/news/ $\underline{\text { Kenya }+ \text { and+Uganda++clash+over+Migingo/-/1056/1901406/-/cljpxw/-/ }}$ index.html

Njiru, M., A. N. Othina, A. Getabu, D. Tweddle, and I. G. Cowx. 2002. Is the invasion of water hyacinth, Eichhornia crassipes Solms ( Mart .), a blessing to Lake Victoria fisheries? Page 396 in I. G. Cowx, editor. Management and Ecology of Lake and Reservoir Fisheries. Blackwell Science, Oxford, UK.

North, R. L., S. J. Guildford, R. E. H. Smith, M. R. Twiss, and H. J. Kling. 2008. Nitrogen, phosphorus, and iron colimitation of phytoplankton communities in the nearshore and offshore regions of the African Great Lakes. Verhandlungen der internationale Vereinigung für Limnologie 30:259-264.

Ochumba, P. B. O. 1990. Massive fish kills within the Nyanza Gulf of Lake Victoria, Kenya. Hydrobiologia 208:93-99. http://dx.doi. org/10.1007/BF00008448

Odada, E. O., W. O. Ochola, and D. O. Olago. 2009. Drivers of ecosystem change and their impacts on human well-being in Lake Victoria basin. African Journal of Ecology 47:46-54. http://dx. doi.org/10.1111/j.1365-2028.2008.01049.x

Okello, W., C. Portmann, M. Erhard, K. Gademann, and R. Kurmayer. 2009. Occurrence of microcystin-producing cyanobacteria in Ugandan freshwater habitats. Environmental Toxicology 25:367-380. http://dx.doi.org/10.1002/tox.20522

Opande, G. O., J. C. Onyango, and S. O. Wagai. 2004. Lake Victoria: the water hyacinth (Eichhornia crassipes [Mart.] Solms): its socio-economic effects, control measures and resurgence in the Winam gulf. Limnologica 34:105-109. http://dx.doi.org/10.1016/ $\underline{\text { S0075-9511(04)80028-8 }}$

Ostrom, E. 2009. A general framework for analyzing sustainability of social-ecological systems. Science 325:419-422. http://dx.doi.org/10.1126/science.1172133
Ponte, S. 2007. Bans, tests, and alchemy: food safety regulation and the Uganda fish export industry. Agriculture and Human Values 24:179-193. http://dx.doi.org/10.1007/s10460-006-9046-9

Poste, A. E., R. E. Hecky, and S. J. Guildford. 2011. Evaluating microcystin exposure risk through fish consumption. Environmental Science \& Technology 45:5806-5811. http://dx.doi. org/10.1021/es200285c

Pringle, R. M. 2005a. The Nile perch in Lake Victoria: local responses and adaptations. Africa: Journal of the International African Institutes 75:510-538. http://dx.doi.org/10.3366/afr.2005.75.4.510

Pringle, R. M. 2005b. The origins of the Nile perch in Lake Victoria. BioScience 55:780-787. http://dx.doi.org/10.1641/0006-3568 (2005)055[0780:TOOTNP]2.0.CO;2

Rutjes, H. A., M. C. Nieveen, R. E. Weber, F. Witte, and G. E. E. J. M. Van den Thillart. 2007. Multiple strategies of Lake Victoria cichlids to cope with lifelong hypoxia include hemoglobin switching. American Journal of Physiology - Regulatory, Integrative and Comparative Physiology 293:R1376-1383. http:// dx.doi.org/10.1152/ajpregu.00536.2006

Schindler, D. W. 2006. Recent advances in the understanding and management of eutrophication. Limnology and Oceanography 51:356-363. http://dx.doi.org/10.4319/10.2006.51.1 part 2.0356

Schindler, D. E., J. F. Kitchell, and R. Ogutu-Ohwayo. 1998. Ecological consequences of alternative gill net fisheries for Nile perch in Lake Victoria. Conservation Biology 12:56-64.

Seehausen, O. 2009. Speciation affects ecosystems. Nature 458:1122-1123. http://dx.doi.org/10.1038/4581122a

Seehausen, O., J. J. M. van Alphen, and F. Witte. 1997a. Cichlid fish diversity threatened by eutrophication that curbs sexual selection. Science 277:1808-1811. http://dx.doi.org/10.1126/ science. 277.5333 .1808

Seehausen, O., F. Witte, E. F. Katunzi, J. Smits, and N. Bouton. 1997b. Patterns of the remnant cichlid fauna in southern Lake Victoria. Conservation Biology 11:890-904. http://dx.doi. org/10.1046/j.1523-1739.1997.95346.x

Sharpe, D. M. T., S. B. Wandera, and L. J. Chapman. 2012. Life history change in response to fishing and an introduced predator in the East African cyprinid Rastrineobola argentea. Evolutionary Applications 5:677-693. http://dx.doi.org/10.1111/j.1752-4571.2012.00245. $\underline{\mathrm{X}}$

Shayo, S. D., C. Lugomela, and J. F. Machiwa. 2011. Influence of land use patterns on some limnological characteristics in the south-eastern part of Lake Victoria, Tanzania. Aquatic Ecosystem Health \& Management 14:246-251. http://dx.doi. org/10.1080/14634988.2011.599607

Silsbe, G. M., R. E. Hecky, S. J. Guildford, and R. Mugidde. 2006. Variability of chlorophyll a and photosynthetic parameters in a nutrient-saturated tropical great lake. Limnology and Oceanography 51:2052-2063. http://dx.doi.org/10.4319/lo.2006.51.5.2052

Sitoki, L., J. Gichuki, C. Ezekiel, F. Wanda, O. C. Mkumbo, and B. E. Marshall. 2010. The environment of Lake Victoria (East Africa): current status and historical changes. International Review of Hydrobiology 95:209-223. http://dx.doi.org/10.1002/ iroh.201011226 
Tamatamah, R. A., R. E. Hecky, and H. C. Duthie. 2005. The atmospheric deposition of phosphorus in Lake Victoria (East Africa). Biogeochemistry 73:325-344. http://dx.doi.org/10.1007/ s10533-004-0196-9

Tumwebaze, R. 1997. Application of hydroacoustics in fish stock assessment of Lake Victoria. Thesis, University of Bergen, Bergen, Norway. http://dx.doi.org/10.1080/14634980701709527

Tumwebaze, R., I. Cowx, S. Ridgway, A. Getabu, and D. N. MacLennan. 2007. Spatial and temporal changes in the distribution of Rastrineobola argentea in Lake Victoria. Aquatic Ecosystem Health \& Management 10:398-406.

van der Knaap, M., and W. Ligtvoet. 2010. Is Western consumption of Nile perch from Lake Victoria sustainable? Aquatic Ecosystem Health \& Management 13:429-436. http://dx. doi.org/10.1080/14634988.2010.526088

van der Knaap, M., M. J. Ntiba, and I. G. Cowx. 2002. Key elements of fisheries management on Lake Victoria. Aquatic Ecosystem Health \& Management 5:245-254. http://dx.doi. org/10.1080/14634980290031947

Van Rijssel, J. C., and F. Witte. 2013. Adaptive responses in resurgent Lake Victoria cichlids over the past 30 years. Evolutionary Ecology 27:253-267. http://dx.doi.org/10.1007/ s10682-012-9596-9

Veraart, A. J., J. J. M. de Klein, and M. Scheffer. 2011. Warming can boost denitrification disproportionately due to altered oxygen dynamics. PloS ONE 6:e18508. http://dx.doi.org/10.1371/ journal.pone.0018508

Verschuren, D., T. C. Johnson, H. J. Kling, D. N. Edgington, P. R. Leavitt, E. T. Brown, M. R. Talbot, and R. E. Hecky. 2002. History and timing of human impact on Lake Victoria, East Africa. Proceedings of the Royal Society of London B Biological Sciences 269:289-294. http://dx.doi.org/10.1098/rspb.2001.1850

Vonlanthen, P., D. Bittner, A. G. Hudson, K. A. Young, R. Müller, B. Lundsgaard-Hansen, D. Roy, S. Di Piazza, C. R. Largiader, and O. Seehausen. 2012. Eutrophication causes speciation reversal in whitefish adaptive radiations. Nature 482:357-362. http://dx.doi.org/10.1038/nature10824

Walters, C., V. Christensen, and D. Pauly. 1997. Structuring dynamic models of exploited ecosystems from trophic massbalance assessments. Reviews in Fish Biology and Fisheries 7:139172. http://dx.doi.org/10.1023/A:1018479526149

Walters, C., and J. F. Kitchell. 2001. Cultivation/depensation effects on juvenile survival and recruitment: implications for the theory of fishing. Canadian Journal of Fisheries and Aquatic Sciences 58:39-50. http://dx.doi.org/10.1139/f00-160

Wanink, J. H. 1999. Prospects for the fishery on the small pelagic Rastrineobola argentea in Lake Victoria. Hydrobiologia 407:183189. http://dx.doi.org/10.1023/A:1003708624899

Wanink, J. H., J. J. Kashindye, K. P. C. Goudswaard, and F. Witte. 2001. Dwelling at the oxycline: Does increased stratification provide a predation refugium for the Lake Victoria sardine Rastrineobola argentea? Freshwater Biology 46:75-85.

Wanink, J. H., E. F. B. Katunzi, K. P. C. Goudswaard, F. Witte, and W. L. T. van Densen. 2002. The shift to smaller zooplankton in Lake Victoria cannot be attributed to the 'sardine'
Rastrineobola argentea (Cyprinidae). Aquatic Living Resources 15:37-43. http://dx.doi.org/10.1016/S0990-7440(01)01145-7

Wanink, J. H., and F. Witte. 2000. Rapid morphological changes following niche shift in the zooplanktivorous cyprinid Rastrineobola argentea from Lake Victoria. Netherlands Journal of Zoology 50:365-372.

Wilkinson, R. G., and K. Pickett. 2009. The spirit level: why more equal societies almost always do better. Allen Lane, London, UK.

Williams, A. E., H. C. Duthie, and R. E. Hecky. 2005. Water hyacinth in Lake Victoria: Why did it vanish so quickly and will it return? Aquatic Botany 81:300-314. http://dx.doi.org/10.1016/ j.aquabot.2005.01.003

Williams, A. E., R. E. Hecky, and H. C. Duthie. 2007. Water hyacinth decline across Lake Victoria - Was it caused by climatic perturbation or biological control? A reply. Aquatic Botany 87:9496. http://dx.doi.org/10.1016/j.aquabot.2007.03.009

Wilson, J. R. U., O. Ajuonu, T. D. Center, M. P. Hill, M. H. Julien, F. F. Katagira, P. Neuenschwander, S. W. Njoka, J. Ogwang, R. H. Reeder, and T. Van. 2007. The decline of water hyacinth on Lake Victoria was due to biological control by Neochetina spp. Aquatic Botany 87:90-93. http://dx.doi.org/10.1016/j.aquabot.2006.06.006

Witte, F., T. Goldschmidt, J. Wanink, M. van Oijen, K. Goudswaard, E. Witte-Maas, and N. Bouton. 1992. The destruction of an endemic species flock: quantitative data on the decline of the haplochromine cichlids of Lake Victoria. Environmental Biology of Fishes 34:1-28. http://dx.doi. org/10.1007/BF00004782

Witte, F., B. S. Msuku, J. H. Wanink, O. Seehausen, E. F. B. Katunzi, P. C. Goudswaard, and T. Goldschmidt. 2000. Recovery of cichlid species in Lake Victoria: an examination of factors leading to differential extinction. Reviews in Fish Biology and Fisheries 10:233-241. http://dx.doi.org/10.1023/A:1016677515930

Witte, F., O. Seehausen, J. H. Wanink, M. A. Kishe-Machumu, M. Rensing, and T. Goldschmidt. 2013. Cichlid species diversity in naturally and anthropogenically turbid habitats of Lake Victoria, East Africa. Aquatic Sciences 75:169-183. http://dx.doi. org/10.1007/s00027-012-0265-4

Witte, F., J. H. Wanink, and M. Kishe-Machumu. 2007a. Species distinction and the biodiversity crisis in Lake Victoria. Transactions of the American Fisheries Society 136:1146-1159. http://dx.doi.org/10.1577/T05-179.1

Witte, F., J. H. Wanink, M. Kishe-Machumu, O. C. Mkumbo, P. C. Goudswaard, and O. Seehausen. 2007b. Differential decline and recovery of haplochromine trophic groups in the Mwanza Gulf of Lake Victoria. Aquatic Ecosystem Health \& Management 10:416-433. http://dx.doi.org/10.1080/14634980701709410

Witte, F., M. Welten, M. Heemskerk, I. Van Der Stap, L. Ham, H. Rutjes, and J. Wanink. 2008. Major morphological changes in a Lake Victoria cichlid fish within two decades. Biological Journal of the Linnean Society 94:41-52. http://dx.doi.org/10.1111/ j.1095-8312.2008.00971.x

Yasindi, A. W., and W. D. Taylor. 2003. Abundance, biomass and estimated production of planktonic ciliates in Lakes Victoria and Malawi. Aquatic Ecosystem Health \& Management 6:289-297. http://dx.doi.org/10.1080/14634980301496 